\title{
¿LA REPARACIÓN DEL DAÑO COMO «TERCERA VÍA» PUNITIVA? ESPECIAL CONSIDERACIÓN A LA POSICIÓN DE CLAUS ROXÍN ${ }^{* *}$
}

\author{
Pablo GALAin PALERMO* \\ PROFESOR ADSCRITO DE DERECHO PENAL \\ UNIVERSIDAD CATÓLICA DE URUGUAY
}

s $\quad$ u m a $\mathbf{r}$ i o

Introducción. I. La reparación y la teoría de la pena. 2. La reparación en el Código Penal Alemán. 3. El Proyecto Alternativo de I992 sobre la reparación. 4. ¿La reparación como tercera vía? 5. La reparación en la praxis alemana. 6. Conclusión.

\section{Introducción.}

Podría decirse que el Código Penal es el catálogo en el que se reúnen los fracasos de una sociedad, aquello que ésta no ha podido resolver de otra forma. Sin embargo, el Código Penal no puede ser la Enciclopedia del fracaso social, albergando todo tipo de comportamiento que la propia sociedad no ha podido resolver por otros medios ${ }^{\mathrm{I}}$. El Código

* Profesor Adscripto de Derecho Penal de la Universidad Católica de Uruguay. Aspirante a Profesor Adscripto de Derecho Penal de la Universidad de la República. Doctorando Derecho Penal de la Universidad de Salamanca.

** La contribución que se ofrece se realizó en usufructo de una beca para una estancia de investigación en el Max Planck Institut für ausländisches und internationales Strafrecht en Freiburg-Alemania (julio-agosto 2003) y ha sido publicada en el libro homenaje a Claus Roxin «La influencia de la ciencia penal alemana en Iberoaamérica», MigUEL ONTIVEROS (redactor responsable), Instituto Nacional de Ciencias Penales, México, 2003. Aquí se presenta con ciertas modificaciones en atención a la Ley I7.726 de 2004 sobre medidas alternativas.

$* * *$ El autor agradece las oportunas consideraciones de los Profesores: Hans-Heinrich Jescheck, Kai Ambos, Adelmo Manna y Jan-Michel Simon.

${ }^{\mathrm{I}}$ Los principios de subsidiariedad y fragmentariedad lo impedirían. El Derecho penal solo puede intervenir ante el fracaso de otros medios de solución del problema, por ello la pena es la «última ratio de la política social y se define su misión como de protección subsidiaria de bienes jurídicos. En 
Penal reúne el catálogo de conductas humanas que en un momento histórico determinado, ponen en peligro los bienes individuales y colectivos más preciados. Allí, con forma de norma previene, motiva y finalmente, amenaza a posibles infractores con una pena. Pero tampoco debe abarcarlo todo. Prevenir, motivar, amenazar y penar conductas que no son de extrema gravedad, lo haría fracasar rotundamente en su cometido.

El sistema penal no puede ser un «cajón de sastre» que albergue todo tipo de herramientas - muchas de ellas inútiles- respecto a la función de mayor importancia que el Derecho Penal debe cumplir en sociedad. Me refiero a la de proteger bienes jurídicos de los más intolerables ataques y solucionar el conflicto causado por el delito ${ }^{2}$. Pero tampoco, la «utilidad» puede conseguirse a cualquier costo, sino de la forma menos lesiva para los intereses de los ciudadanos.

Es así que, por más que el sistema penal deba encargarse de los fracasos sociales, se le debe reclamar eficacia sin que mermen las elementales garantías individuales, aquellas que en líneas generales se encuentran contenidas en la Constitución ${ }^{3}$.

A través de la historia -y no en época muy lejana en el continente americanodistintos sistemas penales, haciendo un mal uso del monopolio de la fuerza, se encargaron de perseguir (a veces, condenar a muerte) a los libre pensadores, disidentes, enemigos políticos o aquellos que defendían la libertad de opinión, puesto que el «sistema» lo entendía necesario para su subsistencia. A solución similar recurren muchos sistemas penales modernos, que demuestran su impotencia -ahora- a través del aumento de las penas, creación de delitos innecesarios o regímenes de «tolerancia cero» ${ }^{4}$. Si bien su

la medida en que el Derecho penal sólo protege una parte de los bienes jurídicos, e incluso ésa no siempre de modo general, sino frecuentemente (como el patrimonio) sólo frente a formas de ataque concretas, se habla también de la naturaleza «fragmentaria» del Derecho penal». Cfe. Claus Roxin, «Derecho Penal. Parte General. Tomo I. Fundamentos. La estructura de la Teoría del Delito», Trad. y notas Luzón Peña, Díaz y García Conlledo, De Vicente Remesal, Civitas, I997 p. 65. Ver también FRANCESCO PALAZZO, «Principi Costituzionali, beni giuridici e scelte di criminalizzazione», en Studi in Memoria di Pietro Nuvolose. Volume Primo, Milano, I99I, p. 37I y ss.

${ }^{2}$ El problema que se ha venido dando, es que con el advenimiento del Estado social (Welfare State) se ha producido un giro en el papel teleológico que cumplía el bien jurídico. Este ha dejado de cumplir una función limitadora para realizar una función de propulsión del Derecho penal, abarcando áreas sociales a partir de principios programáticos que surgen de la Constitución. De esta forma ha colaborado involuntariamente con la inflación del Derecho penal. El Derecho penal no puede cumplir la función de promover valores sociales. Esto lo conduciría a su desnaturalización En ese sentido, ver FERMín MORALES PRATS, «Funciones del derecho penal y sociedad civil», en Il Diritto Penale alla svolta di fine millennio. Tai del Convengo in ricordo di Franco Bricola (Bologna, I8-20 maggio 1995). A cura di Stefano Canestrari, Torino, p. 62 y ss.

${ }^{3}$ Vide, Gastón Chaves, «El Derecho Constitucional y el Derecho Penal» Estudios de la Parte Especial del Derecho Penal Uruguayo. Tomo II, Dardo Preza, Ingranussi, Montevideo, 2000, p. I27 y ss. Ver también, Franco BRICOLA, «Carattere "sussidiario" del Diritto Penale e oggetto della tutela», en Studi in Memoria di Giacomo Delitala. Vol. I, Milano, I984, p. Ior y ss; Roxin, «Derecho Penal. Parte General.», cit, p. 55; EmILIO DolCinI-GIORGIO MARINUCCI, «Costituzione e politica dei beni giuridici», en Scritti in Memoria di Renato Dell'Andro. Vol. I, Cacucci Editore, 1994, p. 27I y ss. . En opinión de FRANCESCO PALAZZO: «Le scelte di criminalizzazione, i beni giuridici e le indicazioni costituzionali sono i sentieri lungo i quali si aggira oggi la scienza penale nel suo attuale idillio con la politica criminale»; obra cit. p. 377.

${ }^{4}$ Ver HASSEMER-MUÑOZ CONDE, «Introducción a la Criminología», tirant lo blanch, Valencia, 200I, p. 328 y ss; HASSEMER, «Persona, mundo y responsabilidad. Bases para una teoría de la imputación en Derecho Penal», trad. Muñoz Conde/Díaz Pita, tirant lo blanch, Valencia, I999, p. 275 y ss.

Redur 3 / año 2005 
política criminal se reduce al simbolismo, la represión y el fracaso, su finalidad es la de ejercer un fuerte control social'.

Dentro de este panorama, el derecho penal no ha podido renunciar a la pena privativa de libertad como pena principal, a pesar que la misma no cumple con los designios de resocialización que exigen las distintas Constituciones ${ }^{6}$.

En vista de este rotundo fracaso político criminal, el legislador ha venido intentando paliar la situación a través de sustitutos a la pena privativa de libertad'. Primero, recurriendo a la pena de multa ${ }^{8}$; luego por medio de sanciones alternativas ${ }^{9}$, algunas de ellas aplicadas en determinadas figuras relacionadas con la ejecución de la pena ${ }^{\text {Io }}$.

Desde el apogeo de la Escuela Positivista el catálogo punitivo ofrece al juez pocas variantes; el sistema vicarial no permite ir más allá de la pena o medida de seguridad para enfrentar el fenómeno delictivo.

Es así como -llegados a este punto- una vez más Claus Roxin ${ }^{\mathrm{II}}$, realiza una propuesta dogmática innovadora. Esta vez propone una «Tercera Vía» (dritte Spur) dentro de la teoría de la pena, que estaría referida básicamente a la reparación voluntaria del daño causado por parte del delincuente. El sistema vicarial se pone en tela de juicio y es nuevamente Roxin quien motiva la discusión científica.

${ }^{5}$ Vide al respecto, DAVID GaRLAND, «Punishment and Modern Society. A study in social theory», The University of Chicago Press, I990; «The culture of control», Oxford Univ. Press, 200I. MUÑZ CONDE, «Derecho Penal y control social», 2da. Edic, Temis, I999.

${ }^{6}$ Vide Pablo GALAin, «La relación existente entre las teorías de la pena y el principio de culpabilidad en el Derecho Penal actual», en Estudios de la Parte Especial del Derecho Penal Uruguayo. Tomo II, Dardo Preza, Ingranussi, Montevideo, 2000, p. I65 y ss.

${ }^{7}$ Según entiende Roxin, «las reacciones en contra de la conducta punible se modificarán ampliamente al retroceder cada vez más la pena privativa de libertad y ser completada o incluso reemplazada por un rico arsenal de consecuencias jurídicas, que si bien presuponen una conducta punible, ya no pueden seguir siendo entendidas como penas en sentido tradicional. Vide, «El desarrollo del Derecho penal en el siguiente siglo», en Dogmática Penal y Política Criminal, Traductor y editor Manuel Abanto, Idemsa, Lima, I998, p. 440.

${ }^{8} \int 40 \mathrm{StGB}$. En Alemania en I990 las privaciones de la libertad ascendían al 5,3\% contra el 83,3\% de las penas de multa impuestas. Cfe KAISER, «Kriminologie»; cit. por ROXIN, «El desarrollo», cit, p. 452. En 200I las multas ascendieron al 86,2\% según datos de la Fiscalía. Staatsanwaltschaften (Arbeitsunterlage) I993 bis 200I jew. Tab. 2.2. Pese a la gran utilización de la pena de multa en Alemania, como bien indica el Profesor Roxin, ésta fracasa frente a los autores que no poseen dinero, o frente a aquellos que lo «ponen a buen resguardo» de la justicia. Vide, «El desarrollo», cit, p. 453.

${ }^{9} \int 43 a, \int 44$ StGB. Roxin propone algunas nuevas penas en vistas de un futuro cercano. Así se refiere en reiterados artículos al arresto domiciliario o a la interdicción en la conducción de vehículos automotores. Vide por todos, «El desarrollo», obra cit, p. 453 y ss.

${ }^{\text {ro }} \sqrt{56 b y ~} \llbracket 56 \mathrm{c} \mathrm{StGB}$.

${ }^{\text {II }}$ Quien en la década del 70 ya había propuesto una «apertura de puertas» de la dogmática penal a los designios de la política criminal, provocando un nuevo ámbito de discusión al sostener la ineficacia de los ontologicismos y la necesidad de solucionar los problemas de la teoría del delito recurriendo a fines de política criminal, en lugar de partir de estructuras lógicas-objetivas que determinaban la acción. Vide «Kriminalpolitik und Strafrechsystem», De Gruyter, Berlin, I970; existe traducción de MUÑOZ CONDE, «Politica criminal y sistema del derecho penal», Bosch, Barcelona, I972. 
Al somero desarrollo de esta propuesta, sin ingresar en la vasta discusión alemana sobre la reparación (Wiedergutmachung) y la conciliación entre el autor y la víctima (TäterOpfer-Ausgleich), se dedican las páginas que siguen.

\section{La reparación y la teoría de la pena.}

I.I. Hoy se acepta pacíficamente que la discusión sobre los fines y fundamentos de la pena, la evolución de su teoría, ha derivado en la discusión explicativa de la esencia del Derecho penal mismo ${ }^{\mathrm{T}}$.

Partir de la idea de que la privación de libertad no debe ser la única consecuencia penal, no parece gran avance en época de aparente dominio funcional o sistémico ${ }^{\mathrm{I} 3}$. Empero, si se dijera que la renuncia a la misma, o su sustitución por sanciones alternativas no quiebran la «coherencia del sistema», en cuanto no merma el mensaje de la norma ni la función de la pena, puesto que, además, derivan del propio ordenamiento jurídico, podría considerarse como tal ${ }^{14}$.

Es así que, más que nunca debe ser definida con claridad, cual es la función del derecho penal. Entendiendo que la doctrina mayoritaria ha aceptado la ruptura definitiva con las estructuras ontológicas como base de la teoría del delito; ahora, los elementos de

\footnotetext{
${ }^{12}$ RoXIN, «Derecho Penal», cit; GÜNTHeR JAKOBS, «Derecho Penal. Parte General. Fundamentos y teoría de la imputación. $2^{a}$ edición, corregida.», trad. de Cuello Contreras y Serrano González de Murillo, Marcial Pons, I997; JESCHECK/WEIGEND «Tratado de Derecho Penal. Parte General», trad. Miguel Olmedo Cardenete, Comares, Granada, 2002; MUÑOZ CondE/GARCíA ARÁN, «Derecho Penal Parte General», 4 a Edic, tirant lo blanch, Valencia, 2002; MIR PUIG, «Derecho Penal. Parte General», $4^{\mathrm{a}}$ ed., corr. y puesta al día con arreglo al Código penal de I995, Aranzadi, Barcelona, I996.
}

${ }^{13}$ En el ámbito de la Sociología, la teoría sistémica establece en líneas generales que: «a. La sociedad es un enorme sistema constituido por una serie de partes interrelacionadas. b. Su fundamento es el funcional-estructuralismo, el cual entiende que la función antecede a la estructura, a diferencia del estructural-funcionalismo, que parte de la existencia de estructuras dadas que deben ser sostenidas por las funciones. c. Los sistemas sociales se construyen a partir de la comunicación. d. Se trata de una teoría generalizadora, multidisciplinaria, que define la sociedad como un sistema autorreferente y autopoiético que se compone de comunicaciones; en el que autorreferencia equivale a un sistema entendido como conjunto de elementos que se relacionan entre sí, teniendo en cuenta el entorno, mientras autopoiesis significa que el sistema puede crear sus propios elementos y la estructura que resulta de ellos». Cfe ÁlvARO ORLANDO PéREZ PINZÓN, «El funcionalismo en la sociología actual», en «El funcionalismo en Derecho Penal. Libro Homenaje al Profesor Günther Jakobs», E. MONTEALEGRE (coordinador), Universidad Externado de Colombia, 2003, p. I23. En sentido penal, lo funcional surge del método teleológico, el cual obliga al Derecho penal a construirse desde o a partir de las consecuencias que él produce. El criterio de sistematización jurídicopenal serán las bases políticocriminales de la moderna teoría de los fines de la pena. Ver Roxin, «Derecho Penal. Parte General», cit., p. 203. La pena, consecuencia natural del Derecho penal, según la función que debe cumplir, debe ser el instrumento que permita la prevención general positiva o integradora -esto es- la reafirmación del derecho frente al delito, como medio de lograr la «fidelidad frente al derecho» de la generalidad y del autor individual. La pena tiene un significado especial, debe demostrar que el comportamiento del infractor no es determinante, pues, lo determinante sigue siendo la norma. «La pena da lugar a que la norma siga siendo un modelo de orientación idóneo». Ver GÜNTHER JAKOBS, «Derecho Penal», cit., p. I4. La legitimación del Derecho Penal se encuentra en la función preventiva y en la persecución de fines políticos. Ver NEUMANN-SCHROTH, «Neuen Theorien von Kriminalpolitik und Strafe», Darmastadt, I980, p. I22.

${ }^{14}$ En sentido similar QUINTERO OLIVARES, «La reparación del perjuicio y la renuncia a la pena», en Estudios penales en memoria del Profesor Agustín Fernández Albor, 1989, p. 595.

Redur 3 / año 2005 
dicha teoría, deberán ser interpretados según coordenadas funcionales o funcionalistas. Para esto, según los fines de la norma -interpretación teleológica- para definir al delito, debemos delimitar en forma previa, que funciones cumple el derecho penal, pero también, que funciones cumple la pena. En este proceso se podrán descartar, aquellas funciones y fines que el derecho penal o la pena, no están legitimados para cumplir.

Al derecho penal se le ha asignado la misión de: a) Proteger bienes jurídicos; b) motivar conductas; c) prevenir en forma general y reafirmar la norma.

Partiendo del respeto de estas funciones, debería analizarse si podría adoptarse sin mayores problemas sistémicos, la reparación como una de los fines de la pena.

Si de encontrar un punto de partida se trata, podríamos hacerlo desde la premisa que la pena no puede servir solamente para infligir un castigo sin ulterior finalidad que el sufrimiento del autor como forma de responsabilizarlo por el daño causado.

Por designio de la Constitución la pena debe servir a la resocialización del individuo, aunque la doctrina sea conteste que en ese caso el modelo tradicional de privación de libertad ha fracasado absolutamente ${ }^{\mathrm{TS}}$.

La pena, desde un punto de vista preventivo general positivo o integrador, debe servir a los efectos de la reafirmación de la norma que ha sido vulnerada por el delito, pero no debe descuidar el mensaje preventivo general negativo, el cual -a nuestro entender- se cumple en forma debida sin necesidad de penas desmesuradas o desproporcionados. Para que la población confíe en su sistema normativo y de justicia, basta con que los ataques más intolerables sean perseguidos y juzgados, sin que hagan falta penas ejemplarizantes ${ }^{16}$. Es más, dichas penas causan el efecto contrario y producen solidaridad con el delincuente, quien en lugar de asumir su responsabilidad, se siente -con razón- a su vez víctima de un sistema «injusto».

La pena debe cumplir con una función retributiva ${ }^{\mathrm{r} 7}$, y con una función preventiva ${ }^{\mathrm{r} 8}$, pero también, la pena debería cumplir una función reparadora, ya sea para con la víctima directa del delito o para con la sociedad en general.

\footnotetext{
${ }^{15}$ Por todos, MuÑoz Conde, ««La resocialización del delincuente, análisis y crítica de un mito», en Cuadernos de Política Criminal n 7, I979, p. 91 y ss. «Las críticas a la resocialización del delincuente no sólo se dirigen contra la resocilización como tal, sino también contra el medio o sistema empleado para conseguirla: el tratamiento penitenciario», Ibidem, p. ıoo.

${ }^{16}$ Vide, E. DOLCINI, «Il castigo sia moderato, ma certo», en Sistema Sanzionatorio: effettività e certezza della pena», Giuffrè Eidtore, 2002, p. 3I y ss.

${ }^{17}$ En lo que respecta al principio de culpabilidad como límite de la pena, aunque pueden existir matices en su gradación en lo que refiere al mínimo de pena y los efectos preventivos; «la pena adecuada a la culpabilidad no tiene sentido en sí misma, sino como instrumento al servicio de un fin político-social». Roxin, «La determinación de la pena a la luz de la teoría de los fines de la pena», en Culpabilidad y prevención en Derecho Penal, trad. De Muñoz Conde, Reus, p. 97. Esa finalidad no es otra que la surge del Estado de Derecho.

${ }^{18}$ Desde el punto de vista de prevención especial, impidiendo al menos una mayor desocialización del sujeto; y desde el punto de vista preventivo general dando el mensaje a la población de que el sistema trata igual a los iguales y desigual a los desiguales sin ulterior diferencia, persiguiendo los delitos que la sociedad en general entiende como «socialmente inadecuados» e intolerables y absteniéndose de actuar cuando la infracción no reviste tal condición o cuando la victima no tiene interés en la persecución del mismo y la investigación de los hechos depende de su exclusiva voluntad. Según entiende Roxin, la prevención general de mayor importancia es la «positiva» o «integradora», de cuyo concepto se derivan tres consecuencias: a) «el efecto motivador pedagógico-
} 
También existe la posibilidad de considerar la reparación como una alternativa a la pena $^{\text {19 }}$, lo que podría encuadrarse dentro de un «efecto premial» ${ }^{20}$ del derecho penal, antes que meramente sancionador. Hasta el momento el código penal alemán ha considerado la reparación del daño como una circunstancia atenuante de la responsabilidad con incidencia al momento de fijar la pena ${ }^{2 \mathrm{r}} \mathrm{o}$ una obligación que se puede imponer para la suspensión condicional de la pena ${ }^{22}$. Pero también, según dispone el $\int 46 a \mathrm{StGB}$, la conciliación realizada entre autor y víctima o el esfuerzo considerable del autor por su consecución, sumado a la indemnización total o parcial del daño, permite al tribunal (en causas menores) ${ }^{23}$ atenuar la pena según el $\mathbb{\int} 49$ StGB o prescindir de la misma.

Si bien se deben aceptar como válidos la mayoría de los argumentos a favor de una revalorización de la víctima, esto debe hacerse dentro de los límites del derecho penal y no

social de aprendizaje, que debe provocar la ejercitación en la fidelidad al Derecho»; b) «el efecto de confianza, que se logra cuando el ciudadano ve que el Derecho se realiza; y c) «el efecto de satisfacción, que aparece cuando el delincuente ha hecho tanto que la conciencia jurídica general se apacigua acerca de la infracción al Derecho y da por finalizado el conflicto con el autor». Conforme, «Fines de la pena y reparación del daño», trad. Julio Maier y Elena Carranza, «De los delitos y las víctimas», ad-hoc, I992, p. I49.

${ }^{19}$ La consideración de la reparación dentro de los fines de la pena podría entenderse legitimada desde y a partir del principio de subsidiariedad de la pena de prisión, la reorientación hacia la víctima y la no desocialización del delincuente. Ver ElENA LARRAURI, «La reparación»; en Penas alternativas a la prisión; Bosch, p. I75.

${ }^{20} \mathrm{Al}$ referirnos al «efecto premial» queremos significar aquellas situaciones en que la norma prevé un beneficio para el autor; lo que no quiere decir que lo premial no pueda hallarse también dentro del catálogo punitivo. En éste encontramos penas y sanciones, y entre ellas distintas gradaciones. El «premio» a la reparación vendría en cuanto la posibilidad de aplicar la pena o sanción más benigna, o incluso en determinados casos, la exención de pena. En el derecho europeo continental generalmente el recurso a la premialidad no se da en sustitución de la pena, sino que se traduce en factores que o bien excluyen la punibilidad o atenúan las consecuencias del delito, ya sea extinguiendo el delito o la pena. En opinión de Bobbio un derecho que premia determinados comportamientos o da relevancia a sanciones positivas es propio de un estado de bienestar, no de uno estático y conservador, protector del status quo, sino de un Estado que intenta programar y reformar la sociedad (NORBERTO BOBBIO, «Sulle zanzioni positive», en AAVV, Scritti dedicati ad Alessandro Raselli, Milano, I97I, p. 238 y ss.).

Es una ventaja del recurso a un derecho premial, el bajo costo político de legislar en forma positiva. A contrario sensu, una política de intervención negativa, contiene efectos deslegitimadores sobre el destinatario no favorecido, mientras que el efecto inverso se da con aquel que se ve favorecido por el efecto premial. A su vez, en caso de errores judiciales, el costo social de un derecho premial es mucho menos lesivo que uno que legisla en forma negativa o represiva.

La función positiva del derecho penal asume roles simbólicos de relevancia social que la función negativa no logra asumir mas allá de la prevención general negativa.

${ }^{21} \ 46$ inc. 2 StGB: «Fijación de la pena: (2) r.En la fijación sopesa el tribunal las circunstancias favorables y desfavorables al autor. 2. En esta relación deben tomarse en consideración de manera particular:...su conducta después del hecho, especialmente su esfuerzo para reparar el daño, así como el esfuerzo del autor de lograr un acuerdo con la víctima».

${ }^{22} \int 56 \mathrm{~b}$ inc. 2. I StGB: Suspensión de la pena. Obligaciones: «El tribunal puede imponer al condenado: I. reparar de acuerdo con sus posibilidades los daños causados por el hecho...»

${ }^{23}$ Que no superen un año de pena de privación de libertad o multa de hasta 360 importes diarios.

Redur 3 / año 2005 
fuera de él. Por tanto, implica analizar la situación también desde la teoría del bien jurídico, el cual merece a esos efectos una re-personalización ${ }^{24}$.

I.2. En aras de la aceptación del modelo reparador, dentro de la teoría de la norma, debemos partir de una concepción dualista-personalista de la misma, donde la norma, además de regla de valoración que valora en forma negativa la conducta realizada (desvaloración), es también una norma de motivación de comportamientos. La función de Ansprechbarkeit o de dialogo normativo, requiere de un interlocutor válido que pueda responder al «llamado» de la norma a través de un proceso de razonamiento interno. El sujeto debe reunir la condición de «abordable» por el mensaje motivador de la norma. Por tanto, la norma tiene a un hombre de capacidad «normal» como su destinatario. Es así, que intentará una orientación normativa -no la simple imposición- ${ }^{25}$ respecto a aquellos comportamientos «no tolerados» en una sociedad determinada.

El ordenamiento jurídico motiva en forma apriorística, al mismo momento que amenaza con una pena en caso de desconocimiento voluntario de tal motivación y actuación en contrario.

El Estado se ve forzado a actuar a efectos de mantener la confianza general en la norma, de otra forma, todo el ordenamiento jurídico perdería paulatinamente su validez.

La utilización del ius puniendi estará justificada solo ante el fracaso motivacional de la norma, la violación de la misma y el ataque efectivo al bien jurídico tutelado, de hacerlo antes, aun con la excusa de la prevención o de una efectiva Defensa social, estaríamos ante una intromisión en los derechos del ciudadano que sería intolerable.

Es en esa línea de pensamiento, que para procederse a una imputación de responsabilidad, el desvalor de acción o comportamiento valorado negativamente, debe traducirse en un resultado dañoso o desvalor de resultado ${ }^{26}$.

\footnotetext{
${ }^{24}$ Ver AlBIN ESER, «Sobre la exaltación del bien jurídico a costa de la víctima», trad. Cancio Meliá, Anuario de Derecho Penal y Ciencias Penales, Vol XLIX fasc. III, I996; «Acerca del renacimiento de la víctima en el procedimiento penal», en De los delitos y de las víctimas, Ad-Hoc, Buenos Aires, I992; «Una justicia penal «a la medida del ser humano» en la época de la europeización y la globalización», trad. de Teresa Manso, Congreso Internacional. Facultad de Derecho de la UNED. Madrid, 6 al io de noviembre de 2002, Separata; J. BAUMANN, «Zur Repersonalisierung des Strafrechts», en W. KÜPER/J. WELP (eds), Beiträge zur Rechtswissenschaft. Festschrift für Walter Stree und Johannes Wessels zum 70 Geburtstag, Heidelberg, I993, p. 42 y ss.

${ }^{25}$ La teoría «monista» de las normas de Binding, podemos considerarla como el opuesto a la que se menciona en este trabajo. Según ésta, el individuo solo debe obedecer el mandato o imperativo normativo, siendo el Estado el destinatario de la misma y no el individuo que solo tiene el deber de sumisión. Ya nos adheríamos a la concepción dualista de la norma en «La relación existente», cit. p. 229.

${ }^{26}$ Dentro de la nueva orientación que sigue mayoritariamente la doctrina penal, además de la causalidad se exige la imputación para que un hecho pueda considerarse un comportamiento con relevancia jurídica penal. Junto a la acción desvalorada debe darse un resultado también desvalorado por el legislador. Esto va a significar que no cualquier resultado dañoso podrá ser imputado a un individuo, sino sólo aquel que pueda con exactitud sostenerse que es su obra. Para ello se ha desarrollado la teoría de la imputación objetiva, para proceder a un primer nivel de imputación, que conecta al sujeto con el resultado, pero también con la teoría del riesgo permitido, puesto que deberá decidirse (según aquello que es de interés penal), que era lo que la norma pretendía evitar se produjera, o mejor expresado, si el resultado acaecido tiene relación con las exigencias normativas derivadas del tipo penal. Sólo de esa forma tal resultado podrá ser imputado (en sentido penal) al sujeto que lo causó según las leyes de la física. La teoría de la imputación objetiva indica que no basta
} 
Estamos convencidos que el sistema penal debe gozar de cierta unidad y congruencia, especialmente entre sus aspectos material y formal. Es así que muchos de los principios que inspiran a la teoría del delito y de la pena, tienen también ingerencia en la materia procesal. La teoría dualista-personalista de la norma, también exige un sistema procesal abierto al diálogo antes que a una búsqueda inquisitiva de la verdad. Delito y proceso son indicadores legales de una situación que debe ser dinámica, como forma de explicar la sociedad «como un proceso de interacción y comunicación» ${ }^{27}$.

Convengamos que desde el punto de vista normativo, la reparación operaría como un «premio» al delincuente que proceda voluntariamente a reparar el daño causado o disminuir los efectos de su acción. De aceptarse la técnica premial, no debería ser la retribución el fin primordial de la pena, pues «esta amarga necesidad> de imponer mal por el mal realizado, no se condice con la función de «premiar» una conducta.

De todas formas, siempre queda un problema por resolver en cuanto a las técnicas premiales, puesto que, como señala Bricola, la técnica del estímulo (incoraggiamento) y la función premial (premiale) del derecho penal, son incompatibles con la esencia y la función de la sanción penal ${ }^{28}$.

Sin embargo, cuando las circunstancias permiten la exención de pena, no pueden caber dudas que el comportamiento positivo posterior del delincuente ha recibido un premio por la «buena acción».

Es indudable que la pena debería tener hoy funciones más importantes, positivas y menos frustrantes que cumplir. Ésta debe prevenir la comisión de delitos ${ }^{29}$, actuando sobre el infractor como sobre la sociedad en general. Pero además, la pena devuelve la confianza a la sociedad en el derecho y en su sistema penal. Aunque para ello, no debe exigir sacrificios innecesarios ni la expiación de la culpa, ni infligir sufrimiento en represalia por

con que se haya producido un riesgo o aumentado uno ya existente -hasta ese momento tolerado(desvalor de acción), sino que el mismo debe transformarse en un resultado dañoso (desvalor de resultado), que a su vez debe coincidir con aquel resultado que la norma pretendía evitar se produjera. Ver Roxin, «Omisión e imputación objetiva en derecho penal», en Jornadas HispanoAlemanas de Derecho Penal, Enrique Gimbernat (Ed.), Univ., Servicio de Publ., Facultad de Derecho Madrid, I994; «La imputación objetiva en el derecho penal», Idemsa, Lima, I997; «Funcionalismo e imputaçao objetiva no direito penal», Trad. e introd. de Luis Greco, Rio de Janeiro, 2002.

${ }^{27}$ HABERMAS, «La lógica de las ciencias sociales», tecnos, Madrid, I988, p. 309; GonZALO FERNÁNDEZ, «Seguridad Ciudadana y reforma procesal», FCU, Montevideo, I995, p. 24 y s.

${ }^{28}$ Aunque podría entenderse con FIANDACA («Il reato commissivo mediante omissione», Milano, I978, p. 67) que el premio estaría en relación con el efecto promocional, en los mismos términos en los que pena se relaciona con la tutela del bien jurídico». Ver F. BRICOLA, «Funzione promozionale, tecnica premiale e Diritto Penale», en Diritto Premiale e Sistema Penale, Milano, I983, p I23.

${ }^{29}$ La norma operó como primera «barrera preventiva», pero ante su fracaso, a través de la pena se vuelve a reforzar el sentimiento hacia el respeto de los bienes jurídicos ajenos o comunes. El Derecho penal pretende motivar al ciudadano a través de conductas que -al ser prohibidas- se tiene la expectativa que no se lleven a cabo. De esta forma realiza una función de prevención a través de la motivación normativa. Ver MUÑOZ CONDE, «Derecho Penal y control social», Temis, 2da. Ed, I999, p. 20; Gimbernat ORDeig, «Estudios de Derecho Penal», zera. Ed, Tecnos, I990, p. I79 y ss; PABlo GALAIN, «La relación», cit. p. 255. De otra opinión BUSTOS RAMíREZ, «Bases críticas de un nuevo derecho penal», ed. Jurídica Conosur, I994, p. I96.

Redur 3 / año 2005 
un mal comportamiento social. La pena puede prevenir, aun a través de su no imposición en caso de no ser necesaria ${ }^{3 \circ}$.

Pero también la «pena» podría consistir en una amonestación con reserva de pena $^{3 \mathrm{I}}$. Lo que realmente importa es que la pena cumpla con su función de solucionar de la forma menos costosa, un grave e intolerable problema social.

Dentro de la búsqueda de los costos mínimos, se debe recurrir necesariamente a la política criminal y a las experiencias de derecho comparado ${ }^{32}$.

La prevención debe comenzar con la norma, pero culminar con la imposición de la pena $^{33}$, siempre que ella sea necesaria a estos mismos efectos ${ }^{34}$.

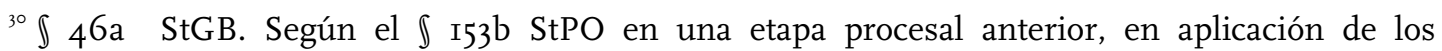
principios de oportunidad y celeridad, puede el fiscal renunciar a la acusación o -en su defectosolicitar el sobreseimiento, siempre que se den las condiciones bajo las cuales el tribunal podría prescindir de la pena.

${ }^{31}$ Según el $\int 59$ StGB cuando el ordenamiento jurídico no exija la condena de una pena y se trate de una pena de multa de hasta i8o días-multa, podrá el tribunal amonestar al autor, determinar la pena y reservar la condena de esa pena, siempre que: «I.sea de esperar que el autor se abstenga en el futuro de cometer hechos punibles aun sin condena a pena. 2. una valoración en conjunto del hecho y de la personalidad del autor demuestran especiales circunstancias según las cuales es procedente que a él se le pueda eximir de la condena a pena».

${ }^{32} \mathrm{Si}$ un ordenamiento jurídico recurriera a la pena de muerte como forma de disminuir el reiterado delito de «secuestro», y las estadísticas indicaran que el número de secuestros no disminuyen -o aun disminuyendo-, aumenta el número de víctimas «asesinadas» por los secuestradores; quiere decir que la pena de muerte no ha servido a los efectos de la prevención del delito y que en contrapartida, un delincuente que se sabe de «antemano», será penado con la muerte, poco le importa que su víctima permanezca con vida en caso de ser detenido por la policía o de haber cobrado el precio del rescate. Esa política criminal además de ser errónea desde el punto de vista de los fines de la pena, produce un alto costo social, contabilizado en número de víctimas. Las víctimas directas del delito y las posibles víctimas de un sistema de «justicia» que -sin ser infalible, o aun siéndolo- condena a penas de muerte. Pero si a ese mismo delincuente, la norma penal, además de no castigarlo con la pérdida de su vida (sino con la de su libertad), le ofrece la posibilidad de considerar como atenuante el hecho de que libere a la víctima antes de la consumación del delito, o lo que es lo mismo, del cobro del rescate, serán mayores las posibilidades de que la víctima sea liberada con vida. La pena de muerte para el delito de secuestro, en lugar de actuar como freno inhibitorio o como función preventiva general negativa, tan sólo disminuiría las posibilidades de que la víctima resulte con vida en caso de no pagarse el precio del rescate. Una política criminal que no considere a la víctima no estaría justificada, por más que pudiera obtener «beneficiosos» efectos preventivo general negativos.

${ }^{33}$ La pena de privación de libertad debe quedar reservada para aquellas situaciones en que deviene imprescindible por razones de seguridad, en consideración de la culpabilidad del sujeto, el daño causado, la forma de llevar a cabo la acción disvaliosa y la importancia del bien jurídico tutelado. Este tipo de pena no puede ser la regla general. Utilizarla de esa forma sería un abuso por parte de quien tiene la potestad de legislar, juzgar y hacer ejecutar lo juzgado, en la peor forma de utilizar el monopolio de la fuerza.

El legislador ha entendido conveniente el recurso a otro tipo de pena que no prive la libertad al sujeto, sin dejar de cumplir los fines que ésta necesariamente debe cumplir. Es así que surge la multa como pena alternativa. Empero sucede que en la mayoría de los Códigos Penales, la pena de multa, siempre que no fuera satisfecha se convierte en pena de privación de libertad. En el caso alemán ver $\ 43$ StGB.

${ }^{34}$ Hay ocasiones en las que la pena no ha sido aplicada, y de todas formas no se ha resentido el efecto preventivo general de la misma. Como dice J.J. QUERALT, «El Estado, es decir, la comunidad política, puede, en ciertas circunstancias, siempre legalmente reguladas, considerar que la 
Es cierto que cada vez que la pena es aplicada, se procede a la reafirmación de la norma como modelo de orientación en el que la ciudadanía (incluido el delincuente) puede confiar. Además, y como complemento, la pena no perderá su efecto intimidatorio. Pero éste no es de mayor importancia dentro de las funciones que la pena tiene que cumplir. Este efecto se relaciona generalmente con aquellos delitos que han causado una «alarma social» que debe ser acallada mediante la acción e intervención del derecho penal. Sin embargo, muchos de los delitos que llegan a los tribunales, son «conflictos» que podrían solucionarse por vías menos costosas al proceso penal tradicional, o con sanciones alternativas a la pena de privación de libertad, o incluso de multa ${ }^{35}$.

I.3. En una sociedad que debe ser más comunicativa, donde debe primar el diálogo como fuente de inspiración de las acciones comunicativas ${ }^{36}$, no debe sustituirse el intento de tal instancia comunicativa por violencia formalizada. Donde sea posible el acercamiento ofensor-victima, este debe propiciarse y no renunciarse a priori ${ }^{37}$.

prevención general se mantiene pese a la no verificación en la realidad de la pena, en cualquiera de las fases procesales de imposición y o ejecución, o cuando tales se condicionan en su virtualidad, en todo o en parte, a que el victimario se someta a la realización de alguna modalidad de reparación». «Víctimas y garantías: algunos cabos sueltos. A propósito del Proyecto Alternativo de reparación», en Política Criminal y nuevo Derecho Penal. Libro Homenaje a Claus Roxin. J.M. Silva SÁNCHEZ ed., Bosch, Barcelona, I997, p. I68.

${ }^{35}$ Respecto al recurso permanente de los jueces a las penas tradicionales, se pregunta ALBIN ESER: «QQuien no iba a poder comprender la decepción de la víctima que al final del proceso penal tiene que soportar que el autor sea condenado a una pena de multa o de privación de libertad, mientras que ella sale con las manos vacías? Y, ¿acaso no se oscurecen aún más las perspectivas de obtener el resarcimiento de daños en un proceso civil por el hecho de que el autor tenga que pagar primero la multa o porque a través del cumplimiento de la pena privativa de libertad incluso se le quita por completo la posibilidad de hacer frente al daño? o, por otra parte, ¿cómo ha de sentirse el autor que ya ha hecho todo para satisfacer por completo a la víctima y a pesar de ello todavía ha de someterse a un procedimiento penal incierto? También aquí se hace patente que lo que pueda resultar beneficioso para la autoafirmación del Estado no necesariamente es justo con los seres humanos directamente afectados». Cfe. «Una justicia penal», cit. p. 23.

${ }^{36}$ En el entendimiento de las acciones comunicativas como aquellas manifestaciones simbólicas (lingüísticas y no lingüísticas) a través de las cuales los sujetos capaces de lenguaje y acción entablan relaciones con la intención de entender sobre algo y coordinar así sus actividades. Vide, JÜRGEN HABERMAS, obra citada.

${ }^{37}$ Sobre el tema «Täter-Opfer-Ausgleich» se recomienda: HEINZ MÜLLER-DIETZ «Was bedeutet Täter-Opfer-Ausgleich im Strafrecht-notwendige Begriffsbestimmungen»; RöSSNER/BANNENBERG «Das Prinzip des Täter-Opfer-Ausgleichs im Allgemeinen Strafrecht-Leitfaden für di Praxis»; en «Täter-Opfer-Ausgleich im allgemeinen Strafrecht. Theorie und Praxis konstruktiver Tatverarbeitung: Grundlagen, Modelle, Resultate und Perspektiven», Bonn, I993; JÜRGEN SCHRECKLING, «Bestandsaufnahmen zur Praxis des Täter-Opfer-Ausgleichs in der Bundesrepublik Deutschland», Bonn I.Verlag Bundesminister d. Justiz, I99I. J. MEYER, «Zur Reform des strafrechtlichen Sanktionensystems unter besonderer Berücksichtigung des Täter-OpferAusgleichs», in Festschrift für Otto Triffterer zum 65. Geburtstag, Wien-New Cork, I996, K. SCHMOller (Hrsg.), p. 629 y ss; MiChAel KilChling, «ktuelle Perspektiven für Täter-OpferAusgleich und Wiedergutmachung im Erwachsenenstrafrecht», NStZ, 1996, Heft 7, p. 309 y ss. Britta Bannenberg/Petra Uhlmann, «Die Konzeption des Täter-Opfer-Ausgleich in Wissenschaft und Kriminalpolitik», en Täter-Opfer-Ausgleich in Deutschland. Bestandsaufnahme und Perspektiven, Bonn, I998, p. I y ss; HORST VIEHMANN „Täter-Opfer-Ausgleich und Strafrecht?», Wiedergutmachung und Strafrechtspraxis. Erfahrungen, neue Ansätze, Gesetzesvorschläge. Bericht über das Forum I992 für Täter-Opfer-Ausgleich und Konfliktschlichtung vom Io. bis I2. April I992 in Bonn, I993, p. 204 y ss.

Redur 3 / año 2005 
El sistema penal debe ofrecer al delincuente la posibilidad de «reparar» su mal acto, por propia voluntad (freiwillig), obteniendo de esa forma ciertos beneficios materiales y formales. Y esto tiene sentido porque el delincuente ha demostrado con su acción que los fines de prevención -especial como general- que la pena habría de intentar cumplir, ya han sido cumplidos al momento de proceder a la reparación (sea material o simbólica) ${ }^{38}$, por lo que podría carecer de sentido y oportunidad la imposición de una pena. Al fin y al cabo, la solución del conflicto debería ser el Leitmotiv del proceso penal, que de ninguna forma puede quedar limitado a la zbúsqueda de la verdad» tout court ${ }^{39}$.

El Derecho Procesal (alemán) tampoco puede admitir que el Estado deba perseguir necesariamente todos los delitos ${ }^{40}$, porque no todos los casos ni las situaciones son iguales, debiendo tratarse desigual a los desiguales, como mejor forma de respetar el principio de igualdad. Sino que tampoco el Estado (basado en el interés público, no el político) puede dedicarse a perseguir todas las infracciones a la ley penal, debiendo reservarse para aquellas que revisten gravedad. Dentro de estos parámetros tendría cabida el principio de oportunidad $^{4 \mathrm{r}}$. El proceso penal no es aconsejable para ciertos delitos ni para determinados infractores, siendo preferible en estos casos, el recurso a una vía alternativa de solución, o directamente reclamar la despenalización de tales figuras. Es indudable que el Derecho procesal penal debe tender a soluciones que busquen el consenso y la verdad formal antes que la inquisición y la verdad material.

\footnotetext{
${ }^{38}$ Cuando la doctrina se refiere a la reparación simbólica, lo hace desde la perspectiva de que la reparación no puede limitarse solamente a los delitos que causan un daño material, sino que también debería abarcar aquellos que no han sido consumados (tentativa fracasada) o algunos delitos de peligro abstracto (conducción imprudente sin consecuencias lesivas). En estos casos la reparación consiste en el pago de una suma de dinero a un fondo de compensación de víctimas. Ver al respecto, CHRISTIAN LAUE, «Symbolische Wiedergutmachung», Duncker und Humblot, Heidelberg, I999; JIN-KUK LEE, «Symbolische Wiedergutmachung im strafrechtlichen Sanktionensystem. Auf der Suche nach der Möglichkeit einer weiteren konstruktiven Tatverarbeitung und Entkriminalisierung durch symbolische Wiedergutmachung», Peter Lang, Frankfurt am Main, 2000.

${ }^{39}$ Vide, MUÑoz CONDE, «La búsqueda de la verdad material en el proceso penal», Lección inaugural curso 1998-1999 Universidad Pablo Olavide, Sevilla.

${ }^{40}$ Ver Ulf KAPAHNKE, «Opportunität und Legalität im Strafverfahren», Tübingen, I982; FRANZ MAYER, «Das Opportunitätsprinzip in der Verwaltung», Duncker \& Humblot, I963; HANS-RAINER MALLUCHE «Opportunitätsprinzip -Überprüfung der Rechtsprechung-»; Würzburg, I978; POTT, CHRISTINE «Die Ausserkraftsetzung der Legalität durch das Opportunitätsdenken in den Vorschriften der $\iint$ I54, I54a», Frankfurt, I996; ERB VOLKER «Legalität und Opportunität», Duncker \& Humblot, Mainz, I999; MARKUS HoRstmanN, «Zur Präzisierung und Kontrolle von Opportunitätseinstellungen», Duncker und Humblot, Köln, 2002; CARLOS AdERITO TEIXEIRA, «Principio da oportunidade», Coimbra, 2000.

${ }^{4}$ El principio de oportunidad surge ante la incapacidad de la Administración de Justicia a la hora de cumplir sus objetivos acorde al principio de oficialidad. Dicho principio -al igual que la penadebería usarse cuando no exista otro remedio mejor. A través del mismo la justicia penal se torna más efectiva, dedicándose a perseguir las ofensas más graves y desechando la criminalidad menor y de bagatela. Para efectivizarlo se requiere otorgar al Ministerio Público la atribución del ejercicio de la acción penal en exclusividad. Además, desde un punto de vista teleológico, el proceso penal no debería tender a la búsqueda de la verdad material, sino de una verdad formal o consensuada. En líneas generales, y en cuanto tiene relación con el proceso penal a través del principio de oportunidad se podrá: a) no iniciar el proceso a instancias del fiscal, siempre que se produzcan determinados requisitos; y b) ponerle fin anticipadamente por efecto de la conformidad entre el acusado y los acusadores. Ver T. ARMENTA DEU, «Pena y proceso: fines comunes y fines específicos», en Política criminal y nuevo.., cit., p. 224 y ss.
} 
I.4. La pena de reclusión -consecuencia por excelencia de los sistemas penales latinoamericanos- debe reservarse para los delitos más graves e intolerables, esos que no pueden solucionarse por vía distinta sin menoscabar otros fines de la pena como son la prevención general negativa y positiva; pero también la retribución con su límite en el principio de culpabilidad. No hace falta decir, que se requiere en nuestro entorno de urgentes reformas procesal penales que eliminen la regla de la prisión preventiva o el procesamiento con prisión ${ }^{42}$.

La pena en sí misma considerada debe tender a la reparación. A la reparación del sistema normativo resquebrajado, a la reparación de las normales condiciones de convivencia pacifica, a la reparación de la «paz jurídica» ${ }^{43}$, sin descuidar a la reparación de la situación de la victima. De esa forma brindaría un mensaje general a la población de estar nuevamente en sintonía con los designios básicos de una pacifica vida comunitaria ${ }^{44}$.

No se debe caer en la confusión terminológica entre la reparación en sentido estrictamente civil y la reparación desde el punto de vista penal ${ }^{45}$. Esta última va mucho más allá de la simple «devolución» del precio de la cosa (y el pago de los intereses o costas y $\operatorname{costos}^{46}$; la reparación del daño causado, para el derecho penal, incluye -además del interés de la víctima- aspectos sociales relacionados con los fines de la pena. Estos no pueden ser

${ }^{42}$ En el sistema penal uruguayo se impone -salvo excepciones- el procesamiento con prisión preventiva, esto ha llevado a que en 1997 el $90 \%$ de las personas privadas de libertad no tuvieran condena. Según Miguel LANGón, Prólogo, «Sistema Penal. Revisión y alternativas» de RAQUEL LANDEIRA Y BEATRIZ SCAPUSiO, Carlos Alvarez Ed., Montevideo, I997, p. 9.

${ }^{43}$ Término utilizado por Roxin en «Zur jüngsten Diskusión uber Schuld, Prävention und Verantwortlichkeit im Strafrecht» en el Festchrift für Paul Bockelmann del año I979, donde se refiere a la «prevención integrativa» o «integradora» como un fin independiente de la pena, donde ésta debe tender a la integración y la satisfacción, recomponiendo la «paz jurídica» alterada por el delito. p. 305 y ss. Existe traducción al castellano de MUÑOZ CoNDE, «Culpabilidad, prevención y responsabilidad en Derecho Penal», en Culpabilidad y prevención en derecho penal, Reus, Madrid, I98I.

${ }^{44}$ Ver en sentido similar, RÖSSNER-WULF, «Opferbezegene Strafrechtspflege. Leitgedanken und Handlungsvorschläge für Praxis und Gesetzgebung», Beihefte zum Rundbrief Soziale Arbeit und Strafrecht, I987, p. 82 y ss; FRANCESCO CAVALLA, «Pena e riparazione», Cedam, Padova, 2000, cit. p. 97. Dice N. AMATO, «La riparazione é una funzione fondamentale, la piú persuasiva e razionale fra quante possono prospettarsi al sistema normativo per risolvere il conflitto, attualizzato dalla consumazione dell'illecito, fra il soggetto aggredito, divenuto soggetto offeso, e il soggetto del dovere, divenuto soggetto offensore». «Diritto, Delitto, Carcere», Milano, I987, p. 93.

${ }^{45}$ Normalmente, cuando se realizan actos de reparación del daño, la consecuencia jurídica penal prevista en la mayoría de las legislaciones es la atenuación de la pena. La satisfacción total del daño material se deja en manos de la víctima y del Derecho Civil, al ser considerada como una consecuencia que se deriva del delito de naturaleza exclusivamente civil. Como si se tratara de una cuestión que depende de la esfera privada del ofendido en la que el derecho público nada tiene que hacer, o de la que no corresponde se ocupe. Para una corriente de la doctrina penal, se debe poner fin a la evolución por separado del proceso civil orientado a la reparación de la víctima y el proceso penal orientado a la penalización del autor. ALBIN ESER, obra cit., p. 24. En esa línea de pensamiento, SusANNE WALTHER, Heinz SCHÖCH y en general los «Profesores Alternativos», aquellos que participaron de la confección del AE-WGM de i992.

${ }^{46}$ Como sucede en el Decreto-ley I4.4I2 de 8 de agosto de I975 sobre Cheques, cuyo art. 59 permite al librador de un «cheque sin provisión de fondos» o «contra una cuenta corriente de la cual no fuere titular» o que tuviera al momento del pago su cuenta corriente suspendida o clausurada, a través de la «reparación material», lograr «la extinción» del proceso penal.

Redur 3 / año 2005 
cubiertos por la reparación civil del daño, y van más allá de la misma. Por eso se relacionan con la teoría de la pena ${ }^{47}$.

I.5. Esta reconsideración de la reparación dentro de los fines del derecho penal, se entiende como una reorientación hacia las necesidades de la víctima ${ }^{48}$. Desde la Victimología se viene exigiendo una ampliación del campo de acción de la prevención añadiendo, de modo «potencial» el objetivo de controlar las consecuencias jurídicas ${ }^{49}$.

Es así que se vuelve a exigir al Derecho Penal ${ }^{50}$ que preste mayor atención a la víctima del delito. Esto podría hacerse satisfactoriamente desde una justicia penal con

\footnotetext{
${ }^{47}$ En primer lugar la pena debería intentar dar satisfacción a la víctima directa de delito. Si esto no llegara a lograrse, mal puede hablarse de un verdadero saneamiento de la perturbación jurídica. La pena presupone reparación, «aunque sólo sea de tal modo que a través del tipo de pena no se frustre dicha reparación». Para el Profesor ESER, «las multas deben destinarse en primera instancia a la indemnización de la víctima y las penas privativas de libertad deben ejecutarse de tal forma que el preso, si es posible, sea exhortado a la reparación a la víctima o que dicha reparación no se haga imposible». Obra cit., p. 24.

${ }^{4}{ }^{8}$ Respecto a la «Opferorientierte» como otros de los aspectos favorables de la Wiedergutmachung, DIETER RÖSSNER, Wiedergutmachung im Strafrecht-Straftheoretische Grundlagen des AE-WGM, Wiedergutmachung und Strafrechtspraxis. Erfahrungen, neue Ansätze, Gesetzesvorschläge. Bericht über das Forum 1992 für Täter-Opfer-Ausgleich und Konfliktschlichtung vom Io. bis I2. April I992 in Bonn, I993, p. 343.

${ }^{49}$ Alessandro Baratta, «La Política Criminal y el Derecho Penal de la Constitución: nuevas reflexiones sobre el modelo integrado de las ciencias penales»; Revista de Ciencias Penales, n 4 , Carlos Alvarez ed., Montevideo, I998, p. 75.

${ }^{50}$ En los sistemas penales del pasado podía recurrirse para la resolución de un conflicto, tanto a la violencia medida o proporcionada como a la reparación del daño. Surge del Código de Hammurabi, 2000 a.c, el \I96: «Wenn jemand einem anderen das Auge zerstört, so soll man ihm sein Auge zerstören», famosa frase del «ojo por ojo, diente por diente»; pero a su vez encontramos a la reparación como pena en los parágrafos \295 o el \260. En el \206 se establecía que para el caso de dar una bofetada o un golpe, se debía pagar la asistencia médica; en el $\ 207$ previa incluso para la muerte una suma de dinero de resarcimiento a los deudos. Cfe. LUDWIG FRÜHAUF, „Wiedegutmachung zwischen Täter und Opfer. Eine neue Alternative in der strafrechtlichen Sanktionspraxis», Verlag Dr. Mannhold Gelsenkirchen, 1988, p. 9. En el antiguo derecho germano «Die Volksrechte», por ejemplo en la Lex Salica, se establecían además de las penas talionarias, penas reparatorias según la entidad de la lesión (『IO, 『II』I2 『I3), de tal modo que si el autor devenía obligado a pagar determinada suma, en caso de cumplimiento no le seria aplicable otro tipo de sanción. Idem, p. I5-I6. Sucede que la reparación del daño (Entschädigung) siempre ha sido otra opción frente a la «devolución del daño» o la represalia (Vergeltung). La reparación del daño dependía del valor de la cosa robada o destruida, de la entidad de la lesión y de la posición social de la victima o lesionado. Era muy importante la función social desplegada por la víctima y debían respetarse las reglas existentes respecto a la reparación dependiendo del tipo de daño y la importancia social y funcional de la víctima. A través de la reparación a la víctima se reparaba también la situación social problemática.
}

Por tanto la Wiedergutmachung como la Vergeltung tienen el mismo origen y son contemporáneas, aunque tienen distintas consecuencias. Ambas nacen consecuencia del interés de la víctima de un control social de la situación injusta, desde la consideración de la situación del individuo que sufre el daño especifico. Sin embargo se recurría en primera instancia a la reparación del daño antes que a la violencia, la cual se utilizaba de manera supletoria y como última ratio. Cfe. FRÜHAUF, cit. p. 29 y p. 32; la cursiva es nuestra.

Por su parte el Derecho Romano consideraba la prevención como fin de la pena sin renunciar a la reparación del daño causado a la víctima. La víctima debía demostrar su resentimiento (ad animum suum non revocaverit de injuriis) para que no se extinguiera su derecho a la reparación por el transcurso del tiempo. El Derecho Romano reparaba el sentimiento de la comunidad ofendida sin 
contenido reparador antes que represivo ${ }^{5 \mathrm{I}}$. De la misma forma se exige al Estado una mayor protección a las víctimas del delito ${ }^{52}$.

En líneas generales, las tendencias doctrinales modernas tienden a una potenciación del papel de la víctima, reconociéndole un papel más activo y de una mayor capacidad de decisión ${ }^{53}$.

\section{La reparación en el Código Penal Alemán.}

El Código Penal Alemán se refiere indistintamente a la reparación con los términos: Wiedergutmachung (reparación), Schadenswiedergutmachung (reparación del daño), Entschädigung (resarcimiento, indemnización, compensación) ${ }^{54}$ y Täter-Opfer-Ausgleich (conciliación o compromiso de reparación entre autor y víctima).

El legislador alemán consideró una mejora de la posición (revaloración) de la víctima a través de la Opferentschädigungsgesetz (OEG) de 1976 con la modificación de fecha 7.I.I985, y la de la Opferschutzgesetz de I986.

A través de la ley de 28 de octubre de 1994 (Verbrechensbekämpfungsgesetz) se introdujo la posibilidad de la Conciliación entre Autor y Victima (Täter-Opfer-Ausgleich), incluso llegando a modificar el Código Penal. Ahora en caso de que el autor se esfuerce hacia la reparación del daño, será considerado positivamente a los efectos de la medición de

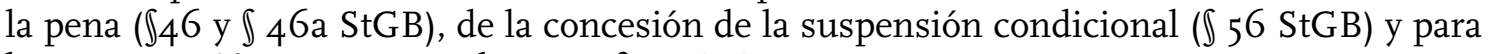
la amonestación con reserva de pena ( $\sqrt{59} \mathrm{StGB})$.

descuidar al individuo directamente perjudicado (magis vindictae quam pecunia habet rationem). Ver, RUDOlF VON IHERING, «La lucha por el derecho», trad. De Adolfo González Posada, Heliasta, Buenos Aires, p. 7I. Ver también J. BAUMANN, «Repersonalisierung», cit. p. 44. Esa efectiva unión entre violencia y reparación dentro del mismo sistema sancionatorio es una de las características más interesantes del antiguo derecho penal.

${ }^{51}$ Siendo por demás contundente, expresa Roxin: «Todo parece indicar que nuestra justicia penal
es, sobre todo, un sistema para hacer fracasar los intereses de la víctima, a pesar de que sería
racional, desde el punto de vista político-social, comenzar, en el intento de una solución del conflicto
social emergente del hecho punible, por colocar a la víctima en situación de indemnidad y recién
después ver si existe algo más que disponer». «La reparación en el sistema», cit. p. I4o. Sin menor
contundencia señala Eser: «La despersonalización del derecho penal y del proceso penal debe
retroceder en la medida de lo posible, siendo prioritario que la reparación a la víctima se entienda
como presupuesto y parte de la sanción». Obra cit. p. 23 .

${ }^{52}$ En el noveno congreso internacional de Victimología llevado a cabo en Ámsterdam en I997, se analizó el tema de la creación de Fondos de Asistencia a las Víctimas. Allí se acordó la necesidad de recurrir a soluciones alternativas de financiación de los mismos, ante la negativa de muchos Estados con respecto a su creación. Entre los modelos vigentes, se puede resaltar el francés que opera a través de una fundación nacional que se financia en parte con una pequeña prima que pagan las compañías de seguro; el canadiense que cobra una ínfima tasa a los condenados o el norteamericano que recauda donativos de las fundaciones. Ver RodRÍGUeZ MANZANERA, «Victimología. Estudio de la víctima», Cuarta edición, Porrúa, México, I988, p. 404.

${ }^{53}$ Ver JAVIER De Vicente ReMESAL, «La consideración de la víctima a través de la reparación del daño», en Política criminal, cit. p. I76.

${ }^{54}$ La Entschädigung generalmente incluye actos de reparación monetaria sin que sean necesarios actos personales por parte del delincuente. Cfe. SUSSANE WALTHER, «Reparation and Criminal Justice: can they be integrated?» Israel Law Review, Summer-Autumn I996, vol. 30, p. 319.

Redur 3 / año 2005 
Por lo que en el Strafgesetzbuch alemán la «reparación del daño» puede consistir en una causa para atenuar la pena o incluso para dispensar su imposición ( $\mathbb{4} 46$ a inc. 2 $\mathrm{StGB}$. La doctrina alemana es conteste en que el esfuerzo reparador que se traduce en una reparación efectiva del daño, puede conducir a una total renuncia a la pena, o al menos a una importante disminución de la misma ${ }^{55}$.

Es importante aclarar que el legislador ha entendido que aunque la reparación cumpliera con los fines de la pena, no sería una pena en sí misma. Sin embargo, cuando el autor se haya esforzado en forma personal para conciliar la situación conflictiva con el ofendido (Täter-Opfer-Ausgleich), entiende que podrían verse cumplidos los mismos, y de esa forma, no ser necesaria la aplicación de otra sanción ${ }^{56}$.

Está claro, que el legislador sólo permite la atenuación o dispensa de pena, cuando haya existido una conciliación (o su intento formal); hecho que no puede darse en todos los casos y que por lo tanto delimita las posibilidades de la reparación como dispensa de pena. No siempre es posible el encuentro entre autor y víctima luego de la comisión de un delito. En algunos casos, incluso no sería aconsejable ${ }^{57}$. La segunda limitación la encontramos en los delitos que pueden ver extinguida la pena por esta vía, contemplados tan sólo aquellos que tengan como pena máxima un año de cárcel o 360 días-multa.

Claro está, si se tratara de un deber que se impone al autor, por ejemplo como una sanción, en opinión del legislador alemán no se justificaría la renuncia o disminución de pena. Pero siempre que se trate de una opción personal del autor (por más que surja de una previa propuesta judicial o fiscal), debería procederse a tal disminución ya que el comportamiento positivo posterior, traería aparejados beneficiosos efectos preventivo generales y especiales.

Sin embargo, hay quienes entienden superflua y un esfuerzo desmedido para ambas partes -salvo en algunos casos muy menores-, la exigencia de una conciliación entre autor y víctima ${ }^{58}$.

Se debería analizar si los fines de la pena no se cumplen con la reparación del daño sin que tenga que operar ese encuentro personal entre autor y víctima. De aceptarse el reingreso de las penas privadas no habría tal inconveniente ${ }^{59}$.

Sin embargo, el espíritu de la Wiedergutmachung va más allá de la simple reparación material, ya que requiere de una reconciliación del autor con la sociedad, especialmente con su víctima ${ }^{60}$.

\footnotetext{
${ }^{55}$ MANFred MAIWALd, «Illecito Penale e riparazione del danno», Désirée Fondaroli, Prefazione, XVII.

${ }^{56}$ JESCHECK/WeIGEND, «Tratado de Derecho Penal», cit, p. 806.

${ }^{57}$ Por ejemplo en delitos relacionados con lo sexual o habiendo mediado violencia en la comisión del hecho.

${ }^{58}$ Vide, J.J. QUERALT, «Víctimas y garantías», cit., p. I67.

${ }^{59}$ Autores como $\mathrm{SCHÖCH}$ reconocen una doble función de la reparación civil. Por un lado se produciría la estricta compensación de los daños sufridos, a la vez que por el otro, se produce una satisfacción adicional al ofendido. Por lo que en determinados supuestos la función de compensación puede verse sustituida por la de satisfacción. En este sentido apoya la propuesta del Proyecto Alternativo ( $\mathbb{I} 6$ y ss), por el cual las partes antes de la imposición de la pena podrían pactar una reparación. VER TAMARIT SUMALLA, «La reparación a la víctima en el derecho penal. (Estudio y crítica de las nuevas tendencias político-criminales)», trad. del catalán Eva Maldonado/Carolina Villacampa, Fundació Jaime Callís, Barcelona, p. 158.
} 


\section{El Proyecto Alternativo de 1992 sobre la reparación.}

Escapa al objetivo de este artículo un análisis detallado del Alternativ-Entwurf Wiedergutmachung (AE-WGM), sin embargo en aras de la coherencia de la exposición, deben destacarse algunos de sus lineamientos principales.

No pueden caber dudas de la importancia del AE-WGM como precedente a la ley de 1994 (Verbrechensbekämpfungsgesetz) ${ }^{6 \mathrm{I}}$. Así como tampoco las puede haber, respecto a la positiva valoración que la doctrina penal y criminológica han realizado sobre el mismo ${ }^{62}$.

En el parágrafo i se define a la reparación como «la compensación de las consecuencias del hecho mediante una prestación voluntaria del autor». De esta forma se obtiene la paz jurídica, fundamentalmente haciendo frente a las necesidades de la víctima, pero «cuando esto no sea posible, no prometa ningún resultado o no sea suficiente por sí mismo, entonces también entra en consideración la reparación frente a la colectividad (reparación simbólica)» ${ }^{63}$.

Las prestaciones de reparación que se exijan no pueden gravar a ninguna de las partes de forma desproporcionada o inexigible; debiendo valorarse los esfuerzos del autor según su situación personal o económica ${ }^{64}$.

Se deduce del articulado propuesto, que la separación tajante entre pena e indemnización civil del daño debe retroceder en el derecho penal del futuro. Al fin y al cabo a ambos los une el mismo fin: la solución de los conflictos ${ }^{65}$.

No se acogen en sus disposiciones ideas abolicionistas, puesto que se entiende necesario el control estatal -antes que la resolución privada del conflicto- como único modo de hacer cumplir también a los poderosos.

${ }^{60}$ En reciente modificación del Código del Proceso Penal (StPO) se han incorporado los $\$ I55a y $\rrbracket$ I55 b relativos a la posibilidad para el fiscal y juez de en cualquier momento de la causa analizar el éxito de una composición entre el autor y la víctima, incluso fuera de la órbita judicial a través de mediadores o árbitros.

${ }^{6 r}$ Ver, «Proyecto alternativo sobre reparación penal. Proyecto de un grupo de trabajo de Profesores de Derecho Penal alemanes, austríacos y suizos», trad. Beatriz de la Gándara Vallejo, Ciedla, Konrad Adenauer Stiftung, I998; JÜRGEN BAUMANN, „Alternativ-Entwurf Wiedergutmachung. Arbeitskreis Deutscher, Österreichischer und Schweizerischer Strafrechtslehrer», Beck, München, I992.

${ }^{62}$ HEINZ SCHÖCH, «Wege und Irrwege der Wiedergutmachung im Strafrecht», en Festschrift für Claus Roxin zum 70. Geburtstag am I5. Mai 200I, de Gruyter, 200I, p. I048; «Der AlternativEntwurf Wiedergutmachung», Wiedergutmachung und Strafrechtspraxis. Erfahrungen, neue Ansätze, Gesetzesvorschläge. Bericht über das Forum 1992 für Täter-Opfer-Ausgleich und Konfliktschlichtung vom Io. bis I2. April I992 in Bonn, I993; BRITTA BANNENBERG, «Wiedergutmachung in der Strafrechtspraxis», Forum-Verl. Godesberg, Göttingen, I993, p. 273; BRAUNS, «Die Wiedergutmachung der Folgen der Straftat durch den Täter», Duncker\&Humblot, Berlin, I996, p. 300; JÜRGEN MEYER, «Zur Reform des strafrechtlichen»,obra cit., p. 633 y ss.

${ }^{6}$ Vide «Proyecto alternativo», cit, p. I3.

${ }^{64}$ Vide $\int 2$ inc. 2 y $\int 3$.

${ }^{65}$ En contra de esta idea y a favor de una separación clara de ambos procesos, BINDING (Normen, vol I, zera. Ed, I9I6, p. 284; cit. en el Proyecto Alternativo, obra cit. p. 39); Hirsch, «La reparación del daño en el marco del Derecho penal material», en Derecho Penal. Obras completas. Tomo III, Rubinzal-Culzoni eds, Buenos Aires, 2002, p. I4I y ss; MuÑoz CONDE/GARCÍA ARÁN, «Derecho penal»; cit. p. 664 .

Redur 3 / año 2005 
En un Derecho penal que debe extender sus consecuencias jurídicas, que debe contemplar la posibilidad de que la paz jurídica se restaure por asunción voluntaria de responsabilidad, tiene cabida la reparación y se fundamenta en el principio de subsidiariedad. Es así que la reparación antecede a la pena cuando no se puede renunciar a una sanción, pero la imposición coactiva de responsabilidad no es necesaria o lo es en forma atenuada ${ }^{66}$.

\section{4. ¿La reparación como tercera vía?}

4.I. ¿Por qué deberíamos descartar de antemano que junto a las penas y las medidas de seguridad, pudiera existir una nueva forma de solucionar el conflicto?.

Siempre se puede pensar en una especie de medida o consecuencia jurídica alternativa (que no tenga naturaleza de pena) que pueda utilizar el juez para sancionar al autor sin necesidad de recurrir a la pena o a la medida de seguridad ${ }^{67}$. De esta forma, no habría inconvenientes para que dentro de estas consecuencias jurídicas se ubicara a la reparación.

Otra opción estaría conformada por la aceptación de la reparación como una pena $^{68}$; aunque éste no es el camino seguido por el AE-WGM.

\footnotetext{
${ }^{66}$ Vide, Proyecto, p. 4I. El recurso a la pena estará justificado cuando los fines que se persiguen con ella no puedan alcanzarse por otro medio menos lesivo. Ese medio menos lesivo sería la reparación. Ver, M. CARMEN ALASTUEY, «La reparación a la víctima en el marco de las sanciones penales», tirant monografías I65, Valencia, 2000, p. 78.

${ }^{67}$ Dice el art. I del Código Penal Tipo Iberoamericano, «Principio de legalidad: Un hecho solo puede ser objeto de pena o de otra consecuencia jurídica prevista en este código, si estas han sido previamente establecidas por una ley formal, proveniente de órgano legislativo democráticamente legitimado». Según Comisión Redactora del Código PenAl Tipo IberoAmeriCANo, «Código Penal Tipo para Iberoamérica. Vol. I», Universidad Externado de Colombia, 2000, p. 2II. El hecho de referirse a «otra consecuencia jurídica prevista en este Código», deja las «puertas abiertas» a la adopción de la reparación del daño como un tipo de sanción alternativa o principal. De esta forma podría entenderse que las condiciones para una tercera vía punitiva estarían dadas. Políticocriminalmente se intenta de esta forma, ampliar el campo de las sanciones penales, más allá de la multa $u$ otras penas alternativas ya conocidas o adoptadas por algunos códigos modernos. Sucede que estas otras «consecuencias jurídicas» que puede llegar a preverse, no tienen por qué tener la naturaleza jurídica de una pena, lo que facilitaría su adopción y evitaría discusiones respecto a su naturaleza jurídica. En opinión de ANTONIO JOSÉ CANCINO, podría tratarse de medidas alternativas o substitutivas a ser aplicadas en determinados casos en que se realiza la conducta típica, pero no deviene necesaria la aplicación de una pena o medida de seguridad. Vide, «El derecho penal, la tercera vía y el principio de legalidad», en «El Derecho Penal Español de fin de Siglo y el Derecho Penal Latinoamericano. Estudios en homenaje a Enrique Bacigalupo», ed. Jurídica Ibáñez, Colombia, I999, p. 89 у I04.

De esta forma los criterios de subsidiariedad y de «necesidad» pasarían a ocupar un lugar de privilegio en la moderna teoría del delito y de la pena.

${ }^{68}$ Una propuesta de este estilo puede verse en los trabajos de KLAUS SESSAR «Wiedergutmachen oder strafen»y Wolfgang Schild, «Täter-Opfer-Ausgleich als Strafe». Las críticas en CARMEN AlASTUEY, cit. p. III y ss. Ahora bien, la reparación como pena no es algo nuevo, tal propuesta fue realizada casi un siglo antes por la Escuela Positivista, entendida como una medida preventiva del delito dentro de los medios de Defensa social. El resarcimiento del daño era de interés público, el Estado debía interesarse de la víctima, por lo que según el art. 9I, el fiscal al momento de solicitar la condena debía necesariamente reclamar el resarcimiento del daño, cuyo monto sería proporcional al
} 
Cosa distinta es que el legislador valore positivamente el comportamiento posterior del delincuente; comportamiento reparador que no tendría que ser exclusivamente material. Esto significa que se acepta y valora positivamente, también a la reparación simbólica.

Sin que lo exprese el AE-WGM, se podría decir que el fundamento de esta beneficiosa consideración legislativa (a modo de premio) pudiera surgir de la «nonecesidad» de pena o «no-necesidad» de medida de seguridad. Por lo que el criterio de necesidad de pena, formulado en sentido negativo (no-necesidad), podría servir de fundamento a esta forma de solucionar el conflicto sin que tenga que recurrirse a una pena ${ }^{69}$.

daño, a la gravedad y modalidad del delito y a las condiciones económicas del condenado (art. 90). Cuando el delito no haya causado un daño económicamente evaluable, el juez podrá exigir o adicionar el pago de una multa. Vide «Progetto Preliminare di Codice Penale Italiano per i delitti. (Libro I). Relazione del Presidente Enrico Ferri», Milano, I92I, p. II3 y I47.

${ }^{69}$ Es difícil encontrar una definición precisa para la «necesidad de pena». (Vide, M. DA CosTA ANDRADE, «Merecimiento de pena y necesidad de tutela penal como referencias de una doctrina teleológico-racional del delito», en Fundamentos de un sistema europeo del Derecho penal. LibroHomenaje a Claus Roxin, Bosch, Barcelona, I995, p. I55). Son pocos los autores que no la consideran conjuntamente con el «merecimiento de pena». (Ver H. OTTO, «Strafwürdigkeit und Strafbedürftigkeit als eigenständige Delikkategorien?», en Gedächtnisschrift für Schröder, München, I978, p. 53 y ss; para quien al momento de valorar un comportamiento como perjudicial, se recurre al «merecimiento de pena», que corresponde a la dañosidad social; mientras que la necesariedad de pena es la respuesta a la finalidad de la pena y se deduce del principio de subsidiariedad. Entonces la pena no será necesaria cuando no ofrezca una posibilidad cierta de prevenir o corregir la dañosidad social). Para autores como VoLK, no es de relevancia una tal diferenciación entre ambas categorías, pues en la práctica no trae consecuencias para el sistema («Ich fasse zusammen: In ihrer Funktion im Straftatsystem lassen sich Strafwürdigkeit und Strafbedürftigkeit nicht unterscheiden...Sie ist daher systematisch und dogmatisch sinnlos». Según «Entkriminalisierung durch Strafwürdigkeitskriterien jenseits des Deliktsaufbaus», en ZStW, 2, I985, p. 899) Están aquellos que sostienen que la «necesidad de pena» o «merecimiento de pena» podría llegar a conformar una cuarta categoría dentro de la teoría del delito, junto a la tipicidad, antijuridicidad y culpabilidad (Ver E. SCHMIDHÄUSER, quien considera el tema desde las condiciones objetivas de punibilidad, las cuales serían «elementos adicionales del delito» que deben añadirse al injusto y a la culpabilidad, para que desde la óptica de la «necesidad de pena» configuren determinados tipos penales. Ver «Objektive Strafbarkeitsbedingungen», en ZStW, 7I, Berlin, I959, p. 545 y ss).

Según SCHÜNEMANN, se requiere en muchas figuras de la parte especial determinar con mayor precisión cuando una conducta es merecedora de pena. Para él, una conducta es «merecedora de pena» (Strafwürdigkeit) cuando ha lesionado o puesto en peligro (en forma culpable) un bien jurídico. Pero que una conducta sea merecedora de pena, no quiere decir que en la oportunidad dicha pena sea «necesaria». Para que la pena sea necesaria, deberá valorarse también, desde un punto de vista teleológico y político criminal, que tal pena no traiga aparejada una consecuencia colateral dañosa que pueda considerarse desproporcionada. La «necesidad de pena» (Strafbedürfnis) requiere de idoneidad, necesidad y proporcionalidad; estos tres requisitos, junto al merecimiento de la antijuridicidad y la culpabilidad, crearían un autónomo presupuesto material del delito. (Ver «Methodologische Prolegomena zur Rechtsfindung im besonderen Teil des Strafrechts» en Festschrift für Bockelmann zum 70. Geburtstag, München, I979, p. I29). Para otros, se trataría de un autónomo «desvalor ético-social» que debe exigirse a una conducta, además de ser típica, antijurídica y culpable. Por tanto, el desvalor total del delito derivaría de tres distintas valoraciones negativas: la antijuridicidad, la culpabilidad y el «merecimiento de pena». (Ver WINRICH LANGER, «Das Sonderverbrechen», Duncker \& Hublot, Berlin, I972, p. 275 y ss).

MARIO ROMANO, las entiende como criterios de interpretación y verificación de la legitimidad del tipo de delito y como categorías heurísticas de política criminal auxiliares del legislador a la hora de

Redur 3 / año 2005 
Por su parte Roxin entiende que el ingreso de la reparación y los intentos de conciliación (o reconciliación) se han convertido en elementos esenciales del sistema de

crear nuevos delitos (Ver «Meritevolezza di pena», «bisogno di pena» e teoria del reato», en Scritti in Memoria di Renato Dell'Andro. Vol. II, I994, p. 803).

En opinión de ROXIN (compartida por LUZÓN PEÑA, «La relación del merecimiento de pena y de la necesidad de pena con la estructura del delito», en Fundamentos, cit, p. II5 y ss) la necesidad de pena tiene relación con las condiciones objetivas de punibilidad, pero a diferencia de las posiciones que buscan una explicación exclusivamente material, la encuentra en la relación entre el derecho penal material y el procesal. Es así como desde el principio de oportunidad ( $\int \mathbb{\int}$ I53 ss StPO), «cuando los $\iiint_{\text {I }} 53$ y I53a hacen depender el sobreseimiento de la escasa culpabilidad y de la ausencia de interés público en la persecución penal, tal interés público sólo puede precisarse según el criterio de los fines de la pena. Y cuando en otros casos puede producirse el sobreseimiento por razones

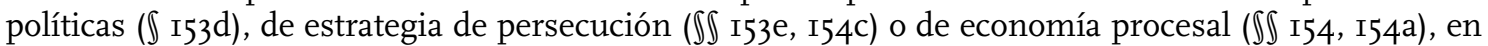
ellos se imponen finalidades extrapenales frente a la necesidad de pena» (Ver «Derecho Penal», cit. p. 990 y ss).

Desde su función político criminal, el principio de necesidad de pena (nullum crimen sine necesítate) o principio de «economía de las prohibiciones penales» busca desde la política criminal restringir al legislador en cuanto a la criminalización de comportamientos. Lo relevante es que estos sean incriminados sólo cuando ello sea absolutamente imprescindible, cuando de no hacerlo se puedan generar males mayores que los que representa la intervención punitiva; esto es, siempre que la pena sea el mal menor, si ésta causa menos daño que lo que representa su ausencia (Ver MARTÍNEZ SÁNCHEZ, «La necesidad de pena en el Derecho Penal Alemán (Strafbeürfnis). Consagración y aplicación en Colombia. Críticas a la teoría de la Imputación Objetiva: entrevista al profesor Jakobs», Colombia, 2002, p. 47 y ss.)

Nosotros entendemos que la «necesidad de pena» no es una cuarta categoría del delito o una nueva valoración negativa que determine cuando hay delito, sino que estaría presente en todos los elementos que se relacionan con el hecho, pero también tienen relación con otros elementos añadidos como las causas de no punibilidad (impunidad para el Código Uruguayo arts. 36 a 45) o las condiciones objetivas de punibilidad, que no son otra cosa que decisiones político criminales del legislador, puesto que no pueden eliminar el desvalor criminal realizado. Este criterio indica que el hecho de que se haya cometido un delito, no trae como consecuencia la necesaria aplicación de una pena. Aun siendo dicha pena «merecida» podría no ser «necesario» su cumplimiento. En este punto se mezclan varios institutos político-criminales, de derecho material relativos al momento de medición de la pena (suspensión condicional, amonestación con reserva, etc) y de derecho procesal (principio de oportunidad, querella privada, etc). En determinadas ocasiones, por razones de política criminal, no habría necesidad de aplicar la pena, puesto que, por ejemplo, el autor ha dado muestras -mediante un comportamiento posterior positivo efectivo de reparación- de que no sería necesaria la aplicación de una pena por necesidades preventivas. Restarían por cumplirse exclusivamente finalidades retributivas. Intentando ser más gráficos, por ejemplo, en delitos contra el medio ambiente, donde se exige que «quien contamine, repare», habiéndose hecha efectiva la reparación del daño, podría aplicarse alguna sanción de menor entidad a efectos de que no se traslade el costo de la reparación a los consumidores o se incluya como «otro gasto» del quehacer empresarial. Pero en determinados delitos de menor entidad, donde pueda ser «restaurada la paz jurídica» sin mayor necesidad de pena, no sería conveniente la aplicación de la misma (Para el caso español ver, PATRICIA FARALDO, «Las causas de levantamiento de la pena», tirant monografías, Valencia, 2000). No coadyuva con esta solución el cumplimiento del fin retributivo de la pena; salvo se entendiera que la reparación ha anulado el efecto negativo del delito en el sentido hegeliano de negación del delito; de esta forma la reparación sería la «negación de la negación» sin que fuera necesaria la pena para tal propósito. Claro, esta hipótesis partiría de una «equiparación» ficticia entre reparación y pena; cuando -según Roxin- , éstas no son de la misma naturaleza jurídica. Por este motivo, la reparación no se condice con un fin retributivo de la pena. Al fin y al cabo, lo importante desde el punto de vista político criminal, es que el sistema no pierda credibilidad mediante la no aplicación de la pena. Así las cosas, se debe concluir que siempre que sea posible prescindir de la pena sin resentimiento de las finalidades que el Derecho penal debe cumplir, esto sería lo sería aconsejable. 
sanciones $^{70}$, a tal punto que conformarían una dritte Spur o tercera vía punitiva. Sin embargo la reparación no es una pena ni una medida de seguridad, sino una medida penal independiente que contiene elementos del derecho civil y cumple con los ya conocidos fines de la pena ${ }^{71}$.

El Profesor alemán entiende conveniente la aceptación de la Wiedergutmachung junto a la pena y a la medida como una tercera vía del Derecho penal. De esa forma, así como la medida sustituye o complementa a la pena, cuando en razón del principio de culpabilidad ésta no se puede justificar (o sólo se puede hacer en forma limitada), «la reparación sustituiría o atenuaría complementariamente a la pena, en aquéllos casos en los cuales convenga tan bien o mejor a los fines de la pena y a las necesidades de la víctima, que una pena sin merma alguna». De esta forma, como el principio de culpabilidad reclama la segunda vía, sería el principio de subsidiariedad el encargado de reclamar la tercera vía ${ }^{72}$.

El ingreso de la Wiedergutmachung en el catálogo de sanciones se justifica por las ventajas político-criminales que traen aparejadas para todos los intervinientes en el conflicto causado por el delito. Esta tercera vía (o por qué no: nuevo catálogo de sanciones), favorece: a) a la víctima específica del delito ${ }^{73}$, b) al autor del delito ${ }^{74}$, c) a la sociedad ${ }^{75}$ y d) a la Administración de Justicia ${ }^{76}$.

${ }^{70}$ «Pena y reparación», trad. de Gimbernat Ordeig, en Anuario de Derecho Penal y Ciencias Penales Tomo LII MCMZCIX, Madrid, 2002, p. 7.

${ }^{7 \mathrm{I}}$ «...Wiedergutmachung keine Strafe ist...sie ist erst Recht. Keine Maßnahme...ich halte sie für eine eigenständige Sanktion, d.h. für eine strafrechtliche Reaktion mit teilweiße zivilrechtlichen Elementen, die keinen neuen Strafzweck ergibt, sondern den herkömmlichen Strafzwecken der Integrationsprävention und der Spezialprävention dient». RoxIN, «Neue Wege der Wiedergutmachung im Strafrecht» en ESER/KAISER/MADLENER, cit. p. 370.

${ }^{72}$ ROXIN, «Fines», cit. p. I55.

${ }^{73}$ La que ve resarcido el daño sufrido. Esto no debe confundirse con la estricta reparación patrimonial o civil del mismo. A los efectos penales, la víctima puede verse satisfecha con una reparación simbólica (un pedido de disculpas, un obsequio), o bien, con «determinados trabajos o prestaciones» que realice el autor, o con el «esfuerzo sincero» por reparar la situación de parte de éste; todo lo cual puede dar por satisfecha a la víctima del delito en un sentido estrictamente penal. Ahora bien, en el entendido que tal reparación aún no es suficiente o no colma sus expectativas en términos patrimoniales, deberá recurrir necesariamente a la vía civil; pues como ya hemos dicho, el Derecho penal no puede cubrir tales expectativas.

${ }^{74}$ Quien acepta voluntariamente la «consecuencia jurídica» que el juez de la causa propone como «vía punitiva». Me refiero a una propuesta de conciliación o reparación del daño, la que también puede provenir del Fiscal en aplicación del $\int$ I55a StPO. Esta norma procesal permite a fiscal y tribunal, en cualquier estadio de la causa, examinar las posibilidades de que autor y víctima puedan

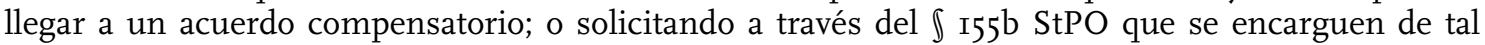
acuerdo árbitros o mediadores de carácter público o privado. De esta forma, se produce un saludable efecto positivo en la psiquis del infractor, quien además de reconocer su hecho, acepta voluntariamente la forma de reparar las consecuencias dañinas del mismo. (LOLA ANIYAR, «La Victimología», Universidad de Zulia, Maracaibo, I979, p. Iı8). Por tanto, se cumple con los designios preventivo-especiales, así como también con los preventivo-generales.

${ }^{75}$ La sociedad no solo ve solucionado el conflicto que el delito ha causado, sino que recibe los beneficios de la resocialización del delincuente, tanto como de la reparación del daño a la víctima individual. La sociedad como víctima mediata del delito, se ve también resarcida ante los efectos positivos de la prevención general positiva o integradora. El derecho es reconocido por el delincuente con su actuación posterior positiva (o en contrario a la primera dañosa). La norma se confirma como orientación de la conducta general de la población. El delincuente recibe su «castigo», el cual es previamente aceptado. El derecho penal funciona, es efectivo, respetando los principios de culpabilidad, legalidad, proporcionalidad, última ratio, subsidiariedad, necesidad de pena e in dubio pro reo. Todo ello dentro de un proceso penal que busca permanentemente, en todas sus instancias,

Redur 3 / año 2005 
Lo importante es el sentido de «reparación»» del daño causado a través de un comportamiento positivo y de alguna forma «reparador». Pero además, como sucede en el trabajo en beneficio de la comunidad, esta sanción debería exigir para ser impuesta, la aceptación del condenado. De esta forma se evitaría caer en un «trabajo forzado». Esta sanción, como puede verse, iría mucho más allá que una reparación civil del daño a la víctima.

4.2. Decía Roxin en i994 que a la reparación no se la debe continuar tratando como una cuestión meramente civil. La reparación debería ser integrada al catálogo punitivo como surge del Proyecto Alternativo de I992- puesto que ésta tiene efectos resocializadores ${ }^{77}$, que van más allá del Derecho civil y atañen a la teoría de la pena. Debe quedar claro en su concepción, que la reparación no llegaría a ser un fin de la pena, ya que en un Derecho penal moderno el único fin posible de la punición es el de evitar (preventivamente) el delito. Esta finalidad abarca a la prevención en todas sus formas ${ }^{78}$. Por tanto, no se necesita un nuevo fin de la pena, siempre que la reparación conforme al principio de subsidiariedad ${ }^{79}$ cumpla con los fines preventivos especiales y generales ${ }^{80}$. Obviamente, además de tener su fundamento en el principio de subsidiariedad, la reparación del daño tendrá que proceder de una consideración distinta del conflicto que causa el delito en la sociedad. De una vez por todas se permite a la víctima participar de esa dialéctica tan particular que se daba entre autor y Estado (representada procesalmente por el

la solución consensuada del problema. Las partes pueden permanecer -de así desearlo- en una situación de confrontación o contradictorio, es también su derecho. Sin embargo, debemos siempre tender hacia la solución menos lesiva, y en ese camino la reparación coadyuvaría con singular éxito a la consecución de soluciones consensuadas.

${ }^{76}$ La cual se evita la realización o prosecución de un procedimiento penal, pero además evita la realización de un posterior proceso civil, al cual debería acudir la víctima para intentar ver resarcidos sus derechos. La reparación permitiría una vía procesal favorable al uso del principio de oportunidad y del archivo de causas o sobreseimiento de determinados delitos de poca entidad cometidos con escasa culpabilidad, donde el interés público no tendría interés en la persecución penal. En Uruguay debido a que la justicia es lenta, burocrática y está sobrecargada de casos judiciales en aplicación del principio de oficialidad de la acción penal, se dictó en el año 2000 la Ley n 17.272 que dispuso el archivo de causas en trámite sin fundamento político-criminal alguno. Se encuentra una crítica al colapsamiento de los procesos penales en Uruguay en «Aspectos Penales de la Ley N I7.272 (Gracia y Clausura de procedimientos penales)», José LUIS GONZÁLEZ, en La Justicia Uruguaya, tomo I24, 200I, p. D-I25 y ss.

77 «Der Alternativ-Entwurf Wiedergutmachung (I992) legt einen ausformulierten Gesetzesvorschlag vor, durch den die Wiedergutmachung in das strafrechtliche Sanktionensystem integriert werden könte. Die Wiedergutmachung ist nach dieser Konzeption nicht mehr eine rein zivilrechtliche Frage, sondern trägt Wesentliches auch zur Erreichung der Strafzwecke bei. Sie hat resozialisierende Wirkung». «Strafrecht Allgemeiner Teil, Band I, Grundlagen. Der Aufbau der Verbrechenslehre», 2. Auflage, C.H.Beck sche Verlagsbuchhandlung, Manchen, I994, p. 64-65.

${ }^{78}$ Vide Roxin, «Fines», cit. p. 146 .

${ }^{79}$ En opinión de Tamarit correspondería hablar en lugar de principio de subsidariedad, de «principio de subsidiariedad de la pena», ya que lo que interesa es reducir el grado de aflicción de la sanción. Detrás de esta tercera vía punitiva, lo que hay es un principio de «mínima aflicción» o de la «sanción mínima», idea que también subyace al principio de humanidad o de benignidad de las sanciones. Vide, «La reparación», cit, p. I85.

${ }^{8 \circ}$ «Die rechtspolitische Legitimation der Wiedergutmachung als einer «dritten Spur» unseres Sanktionesystems liefert das Subsidiaritätsprinzip...Außerdem ist die Wiedergutmachung der Integrationsprävention sehr dienlich, indem sie einen bedeutenden Beitrag zur Wiedergutmachung des Rechtsfriedens leistet», ibidem, p. 65. También en «Neue Wege», cit., p. 374. 
abogado defensor y el representante del Ministerio Público) para convertirla en un diálogo de tres.

Es lo que se ha venido a llamar «la revaloración de la victima» ${ }^{8 \mathrm{r}}$, en el entendido que no se protege adecuadamente a la víctima privatizando una cuestión pública, sino que se debe intentar de la forma más eficaz posible, una vuelta a la «normalidad» a través del restablecimiento de la «paz jurídica» ${ }^{{ }_{2}}$. Para ello es de suma necesidad contemplar los intereses del perjudicado por el delito, a quien hasta ahora el sistema penal no tomaba en consideración $^{83}$; o peor aun, lo perjudicaba en sus intereses reparatorios a través del encierro del criminal o de la aplicación de una pena de multa ${ }^{8_{4}}$.

4.3. Durante mucho tiempo la dogmática penal alemana, centró su discusión respecto al hecho de si el delincuente debía «expiar» su culpa por el delito causado ${ }^{85}$. La expiación de la culpa ha sido siempre algo individual, que no debería tener mayores repercusiones sociales. Es un «estado del alma» que sólo el delincuente puede valorar y que ningún juez o legislador pueden imponer o pretender que con una pena se cumpla. El Estado, como ente laico $^{86}$, no puede inmiscuirse en «asuntos» propios de las religiones o de los individuos como tales. Éste sólo debe, en cumplimiento de la función de ejercer el monopolio de la

\footnotetext{
${ }^{81}$ Ahora, también desde el punto de vista sistemático la teoría de la pena debe contar con los intereses de las víctimas. Teniendo en cuenta sus intereses se añade algo más al concepto normativo de los fines de la pena. La reparación o satisfacción de la víctima significa algo más que el resarcimiento material del daño causado; «con la reparación a la víctima se hace referencia también a algo normativo; a saber, la rehabilitación de la persona lesionada, la reconstrucción de su dignidad personal, el trazado inequívoco de la línea entre un comportamiento justo y uno injusto, la constatación ulterior para la víctima de que, efectivamente ha sido una víctima (y no un delincuente ni tampoco el protagonista de un simple accidente)...; la categoría penal de la víctima está configurada de forma más ambiciosa y su alcance es mayor. «Víctima» de un delito somos todos nosotros, naturalmente no en sentido empírico pero sí en sentido normativo». Cfe. WINFRIED HASSEMER, «Persona», cit, p. I98 y ss.

${ }^{82}$ BACIGALUPO, «Alternativas a la pena privativa de libertad en el Derecho Penal Europeo Actual», en Cuadernos de Doctrina y Jurisprudencia Penal, año III, numero 6, Ad-Hoc, p. 76.

${ }^{83}$ El autor, del cual se han ocupado y preocupado tradicionalmente la ciencia penal, la praxis y la política criminal, ha perdido atractivo así como la posición central que ocupaba en nuestra percepción del delito. Nuestra atención, nuestro interés y también nuestra compasión caminan desde el autor hacia la víctima («Unsere Aufmerksamkeit, unser Interesse und auch unser Mitgefühl wandern vom Täter zum Opfer»). WINFRIED HASSEMER/J.P REEMTSMA, «Verbrechensopfer. Gesetz und Gerechtigkeit», Verlag Beck, München, 2002, p. I3. Se desprende de su pensamiento, que al ser incluida la reparación del daño dentro de los fines del derecho penal, las potenciales víctimas, o sea la población en general, se sienten mejor protegidas por el sistema, lo que conforma un saludable efecto preventivo general positivo.

${ }^{84}$ Consecuencia de la tajante separación entre el Derecho penal y el civil, luego de haber cumplido su pena y «reparado» el delito con la sociedad y el Estado (fin de la pena y del Derecho penal), poco interés (o dinero) tiene el autor en asumir ulteriores reparaciones respecto al verdadero perjudicado por el delito (reparación del daño como fin de la condena civil).

${ }^{85}$ KART EISNER, «Schuld und Sühne», Verl. Neues Vaterland, Berlin, I9I9; F.W. FoerSTER, «Schuld und Sühne», Beck, Manchen, I9ıı; PAul BocKelmANN, «Schuld und Sühne», Vandenhoeck \& Ruprecht, Göttingen, I957; GERHARD MAUZ, «Das Spiel von Schuld und Sühne», Dusseldorf, I975; M. POTT, «Schuld und Sühne im Gelobten Land», Kiepenheuer \& Witsch, Köln, 2002.

${ }^{86}$ Vide, GIOVANNI FIANDACA, «Laicità del Diritto Penale e secolarizzazione dei beni tutelati», en Studi in Memoria di Pietro Nuvolone. Volume Primo, Milano, I99I, p. I67 y Ss; FERRANDO MANTOVANI, «Problema della laicità nell'esperienza giuridico-penale», en Scritti in Memoria di Renato Dell'Andro. Vol. I, Cacucci Editore, I994, p. 5I9 y ss; FERMín MORALES PrATS, «Funciones», cit. p. 69 .
}

Redur 3 / año 2005 
persecución de los delitos, solucionar el conflicto que el delito causa, de la manera más efectiva y menos costosa. Los costos medidos en términos sociales y no monetarios ${ }^{87}$. Es así que podría preferirse una consecuencia jurídica «reparadora» antes que una pena en el sentido tradicional, toda vez que lo permitan los principios de culpabilidad, proporcionalidad y necesidad.

Por lo tanto, ahora que parecería haber disminuido la intensidad de tal discusión filosófica ${ }^{88}$, dentro de un derecho penal con mayor orientación hacia las consecuencias ${ }^{89}$, deberíamos empezar a preguntarnos con mayor insistencia, si el juez podría brindar al delincuente la posibilidad de «reparar» el daño causado, en el entendimiento que se trata de una forma de «cumplimiento de pena» o de una acción que tras haber cumplido con los fines de la pena, torna innecesaria («no necesidad de pena») la aplicación de una sanción penal.

4.4. Por otra parte, con respecto al bien jurídico y a la función que le corresponde dentro de la teoría del delito, debemos decir que éste será determinante en cuanto una revalorización de la reparación dentro del sistema penal. Según Quintero la reacción reparatoria puede ingresar al derecho positivo por dos vías: a) a través de la despenalización de determinadas conductas que deberían ingresar en el ámbito civil o administrativo; y b) vigorizando la función reparatoria dentro de las consecuencias penales. Para la decantación por una u otra vía, se debe previamente valorar los intereses en juego, puesto que será a partir del bien jurídico tutelado en cada caso, que pueda plantearse la tutela de los mismos y las consecuencias penales para su lesión ${ }^{90}$. La función reparadora debe centrarse en aquellos bienes jurídicos personalísimos (el honor, la intimidad), patrimoniales (sin que haya mediado violencia o intimidación) o en aquellos económicos contra intereses supraindividuales (delitos fiscales contra la Hacienda pública) ${ }^{91}$. En todos estos casos, la reparación del daño podría hacer no necesaria la aplicación de una pena, o al menos, de una pena privativa de libertad. No encontramos impedimentos tales que tornen de imposible realización, la tarea de revalorizar la posición de la víctima ${ }^{92}$ y admitir a la reparación del

\footnotetext{
${ }^{87}$ Aunque la privación de libertad y sus costos monetarios es un gran problema que enfrentan los sistemas penales latinoamericanos -que como el Uruguay- tienen a la prisión preventiva como regla y no como excepción. Ver art. 7I Código Procesal Penal y Ley n I5.859 de 3I/5/I987.

${ }^{88}$ Todavía se refiere a la expiación conjuntamente con la prevención general SEELMANN, como forma de delimitar a la reparación exclusivamente dentro del Derecho penal. La reparación desde un punto de vista simbólico tiene relación con la expiación, pues permite la reconciliación del delincuente, no sólo con la víctima sino con la sociedad en general. Ver «Strafzwecke und Wiedergutmachung», cit. p. I54 y ss.

${ }^{89}$ Ver por todos HASSEMER, «Fundamentos del Derecho Penal», trad. Muñoz Conde/Arroyo Zapatero, Bosch, I984.

${ }^{9 \circ}$ Desde la misión del derecho penal como protector de bienes jurídicos en ultima ratio y con carácter fragmentario, puede sostenerse con Roxin, que muchas figuras penales deberían salir de la esfera de lo penalmente relevante. Ver «El desarrollo de la Política Criminal desde el Proyecto Alternativo», trad. de J.J. Queralt, en Mir editor, La reforma del Derecho penal, Bellaterra, I980, p. 87.

${ }^{91}$ QUINTERO OLIVARES, «La reparación», cit. p. 589 y ss.

${ }^{92}$ En muchos casos - de ser posible- aumentando la posibilidad de ejercicio de la acción penal por propio interés; todo lo que se conseguiría a través del aumento de los delitos perseguibles a instancia del ofendido. Esto minimizaría la crítica sobre que la víctima pueda disponer sobre la imposición de una pena, puesto que muchos delitos que el Estado se irroga la potestad, son de casi exclusivo interés del damnificado. Pero también se puede ir más allá y sostener que tales delitos ni siquiera deberían integrar el catálogo de figuras penales. Dejar en manos de la víctima la persecución del delito no significa una merma del principio de persecución pública, si tenemos en cuenta que en I99I en
} 
daño como una alternativa a la pena, siempre que las mismas no resientan el interés público en la persecución de determinadas conductas ${ }^{93}$.

Ahora bien, el interés público será aquel que surja de la interpretación de los principios que informan al derecho penal, no distorsionen el sistema, y se deduzca de los fines que la pena debe cumplir para la resolución del conflicto. Otro tipo de interés carecería de justificación.

Pero también, la reparación del daño puede tener efectos en el proceso penal, provocando el archivo de las actuaciones o la extinción del proceso a través del sobreseimiento. El hecho de la sujeción a un proceso penal causa en el individuo similar efecto estigmatizador al de la aplicación de una pena ${ }^{94}$.

4.5. La posición de Roxin ha recibido críticas desde algunos sectores dogmáticos. En este aspecto Hans Joachim Hirsch ha sido quien con más énfasis ha fustigado la propuesta de la «tercera vía». En líneas generales sostiene que de admitirse esta nueva idea la víctima antes que beneficiada se vería perjudicada en sus intereses ${ }^{95}$. Una condena a la reparación del daño no significaría nada nuevo puesto que también puede ser obtenida por la víctima a través de un procedimiento civil. Sólo se podría considerar que su posición es ventajosa desde el momento en que se entendiera la reparación como una sanción que en caso de incumplimiento se convirtiera en pena de privación de libertad ${ }^{96}$. Sin embargo, esta propuesta significaría nada menos que la restauración de la prisión por deudas. Nosotros debemos indicar que del análisis de distintos trabajos de Roxin sobre el tema, no hemos encontrado en los mismos una proposición similar.

La «espada de Damocles» que pende sobre el delincuente que no «accede» o se decide voluntariamente a reparar el daño, nada tiene que ver con la amenaza de una pena privativa de libertad (ni otro tipo de pena) ante el incumplimiento del acuerdo de reparación. Al delincuente que incumple tan sólo lo espera como «castigo» la continuación del proceso. No podemos negar la presión que se ejerce desde el proceso penal sobre el delincuente con el objetivo de obtener un fin civil: la reparación del daño. Pero debe quedar claro que esa presión no se realiza bajo la amenaza de una pena privativa de libertad en caso de no

Alemania cerca del 90\% de los procesos fueron iniciados a través de denuncia de la víctima. Ver B.D MEIER «Umleitung der Geldstrafe für Zwecke der Wiedergutmachung. Überlegungen zur Berücksichtigung von Verletzteninteressen in der Strafvollstreckung», en ZRP Heft 2, I99I, p. 69. En fechas más recientes, el número de denuncias (private Anzeigeerstattung) ha aumentado a cifras que van entre el 9i y el $98 \%$ de los casos ventilados en la justicia penal alemana. Ver, G. KAISER, «Kriminologie. Ein Lehrbuch. 3., völlig neubearbeite und erweiterte Auflage», Heidelberg, Verlag, I996, p. 56 I.

${ }^{93}$ De opinión similar, MORALES PRATS, cit. p. 73.

${ }^{94}$ En el mismo sentido, Morales Prats, cit. p. 74.

${ }^{95}$ También SEELMANN analiza determinadas paradojas respecto a la orientación del Derecho penal hacia la víctima, donde cuestiona que todo lo que se dice y hace a favor de la víctima, puede resultar no tan favorable para los intereses de ésta. Pero además, puede darse la paradoja de ocuparse de una víctima concreta dejando fuera de consideración a las víctimas potenciales. Ver «Paradoxien der Opferorientierung im Strafrecht», JZ, I989, p. 67I.

${ }^{96}$ HIRSCH «La reparación», cit. p. I49. Al respecto de esta posibilidad sostiene HEIKE JUNG, que utilizar la Wiedergutmachung como si de una Compensation Order anglosajona se tratara, llevaría a la desnaturalización de este instituto. «Compensation order-Ein Modell der Schadenswiedergutmachung?», ZStW 99, I987, Heft, 3, p 260. 
realización, sino de la pérdida de posibles beneficios (o premios) materiales o formales. Cosa diferente es que se fustigue la voluntariedad de la reparación, cuando la decisión parecería ser obtenida a través de la coacción de la iniciación de un proceso penal para el caso de no llevarse a cabo los actos reparatorios.

Partiendo de una idea retributiva de la pena, entiende Hirsch que la víctima ve resarcido sus intereses cuando el autor recibe un «justo castigo», puesto que la pena sólo puede influir sobre el autor, y el hecho que «que la víctima obtenga una indemnización configura un camino ajeno a estos fines.» ${ }^{97}$. En su opinión la «tercera vía» no sólo sería una consecuencia jurídica ajena al Derecho penal, sino también desacertada en sus consecuencias $^{98}$.

También dirige sus críticas refiriéndose a los delitos sin víctima individualizada y a los delitos tentados en los cuales no se ha producido daño, ya que aquí no habría posibilidad de reparar y sin embargo no se puede prescindir de la pena. Según Hirsch, esta situación conllevaría a una gran desigualdad en la reacción frente a los delitos ${ }^{99}$.

Se dice que la reparación no puede constituirse en una invitación para delinquir contra bienes jurídicos patrimoniales, ya que la «prevención general no puede ser sustituida por la invitación general» ${ }^{\text {roo }}$. Además, se dice que la reparación favorece sólo a los autores que pueden disponer de dinero para hacer frente al resarcimiento del daño y beneficiarse por ejemplo con una disminución de pena ${ }^{\text {ror }}$.

En definitiva, el proyecto alternativo y la propuesta de la «tercera vía», en opinión de Hirsch, solo han servido para que el autor logre a través de la reparación del daño la posibilidad de obtener consecuencias jurídicas penales atenuadas; las que de todas formas, sólo se aplicarían en casos marginales ${ }^{\mathrm{IO2}}$.

Por nuestra parte, consideramos de gran valía las críticas realizadas a la inclusión de una tercera vía conformada por la reparación pues son una indudable contribución al

${ }^{97}$ «La reparación»; cit. p. I47. Esta opinión se opone a las investigaciones criminológicas que comprueban el interés primordial de la víctima en el resarcimiento del daño. Ver K. SESSAR, «Wiedergutmachen oder Strafen», Pfaffenwieler, I992; H.J. ALBRECHT, «Kriminologische Perspektiven der Wiedergutmachung. Theoretische Ansätze und empirische Befunde», en ESER/KAISER/MADlENER (Hrsg.), Neue Wege der Wiedergutmachung im Strafrecht, Freiburg i.Br., I990, p. 46 y ss.

\footnotetext{
${ }_{98}^{8}$ La reparación», cit, p. 142 .
}

99 Ibidem, p. I50. Respecto a la desproporción entre distintas conductas delictivas MUÑOZ CONDE/GARCÍA ARÁN: «...mientras la pena debe ser proporcionada a la gravedad del hecho, la responsabilidad civil debe ser equivalente al daño o el perjuicio ocasionado por el mismo, que puede ser inferior o superior a la gravedad del delito». En esa línea de razonamiento se ejemplifica de la siguiente forma: «el terrorista que coloca un explosivo en un establecimiento provocando la rotura de sus cristales y la imprudencia de tráfico que provoca una tetraplejia en la víctima; evidentemente, la reacción penal no podría atender sólo a la reparación del daño porque sería abiertamente desproporcionada: o bien se impone una pena excesiva en una conducta leve o bien se impone una pena ridícula en una conducta grave». Cfe. «Derecho Penal», cit. p. 664.

${ }^{\text {Ioo }}$ La legislación no puede convertirse en una provocación para delinquir, esto dicho desde el punto de vista que el autor con la comisión del delito solo arriesga una posible reparación, a la que de todas formas estaría obligado por el Derecho civil. «La reparación», cit, p. I53.

${ }^{\text {Ior }}$ En concreta respuesta a esta objeción Roxin propone para este tipo de autor insolvente un trabajo sustitutorio en beneficio de la comunidad. Cfe. «Pena», cit. p. I2.

\footnotetext{
${ }^{102}$ «La reparación», cit, p. I70.
} 
debate $^{\text {ro3 }}$. Ahora bien, en relación a las críticas de Hirsch, correspondería tan sólo decir, que su punto de partida desde una concepción predominantemente retributiva de la pena, no se condice con la posición actual de la doctrina dominante.

\section{La reparación en la praxis alemana.}

Según datos provenientes del Ministerio Público (Staatsanwaltschaften) en el año 200 I de 4.555 .675 procesos investigados, se acusó en 258.797 , llegándose a una pena de multa en $208.379(80,5 \%)$. Por su parte, en ese mismo año se procedió a la Wiedergutmachung en 16.246 casos $(6,3 \%)$ y en 2.548 oportunidades (I,O\%) se derivó a Täter-Opfer-Ausgleich.

Mientras que de las cifras provenientes de la práctica de los Tribunales penales (Strafgerichte) en el año 2001 se tramitaron I.oI9.554 procesos, habiéndose producido Wiedergutmachung en 7.347 (9,0\%) y T-O-A tan sólo en 372 (0,5\%).

Llegados a este punto se debe resaltar el hecho de que las ventajas prácticas que la doctrina alemana encuentra en la Wiedergutmachung ${ }^{104}$, según indican las cifras expuestas supra, parecerían no tener acogida por parte de los ordenadores prácticos del sistema penal. En la praxis, en cuanto refiere a los delitos cometidos por mayores de edad, tanto el Ministerio Público como el Juez no solicitan con frecuencia la reparación y conciliación entre autor y víctima, cuando tienen la posibilidad de hacerlo -a lo largo de las distintas etapas procesales- recurriendo a los parágrafos $153 \mathrm{StPO}$ y $46 \mathrm{a}, 56 \mathrm{~b}$ y $57 \mathrm{StGB}^{\text {105 }}$. Asimismo

${ }^{\text {I03 }}$ Vide FRITZ LOOS, «Zur Kritik des Alternativentwurfs Wiedergutmachung», ZRP, I993, Heft 2, p. 5I y ss; JOACHIM LAMPE, «Wiedergutmachung als “dritte Spur” des Strafrechts?», Goltdammer's Archiv für Strafrecht, I993, Heidelberg, p. 493 y ss; SCHMIDT-HIEBER, «Ausgleich statt Geldstrafe», NJW, I992, n 32, p. 2000 y ss; ROMANO, «Risarcimento del danno da reato, diritto civile, diritto penale», en Riv. It. Dir. Proc. Pen., I993, p. 865; M. CARMEn AlASTUEY, «La reparación», cit, p. 89 y SS.

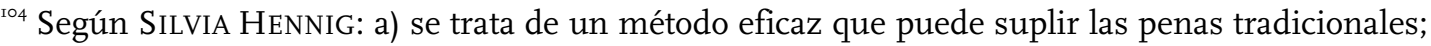
b) que soluciona con rapidez la reparación del daño respecto al delito; c) demuestra la efectividad del sistema respecto a la victima; d) en materia de derecho penal juvenil no se produce anotación en cuanto a antecedentes, todo lo que no perjudica al menor en lo que refiere a disminución de oportunidades para conseguir un trabajo o en su profesión o formación; además de ser un saludable efecto pedagógico; y e) tras la mediación puede el autor incluso llegar a reconciliarse con su victima. Cfe, «Täter-Opfer-Ausgleich und Mediation. Methoden und Beispiele-Zweifel und ketzerische Gedanken», in «Täter-Opfer-Ausgleich. Beiträge zur Theorie, Empirie und Praxis», GÜNTHER GUTSCHE/ DiETER RÖSSNER (Hrsg.), Forum Verlag Godesberg, 2000, p. 219.

${ }^{\text {105 }}$ En cifras que provienen de la StBA- Staatsanwaltschaften (Arbeitsunterlage) I993 bis 200I (ab I995 mit NBL), jew. Tab. 2.2; Prozentuierungen nach eigener Berechnung, podemos indicar que los Fiscales alemanes en I999 instauraron 4.495.556 procesos de investigación (Ermittlungsverfahren insgesamt), de los cuales acusaron (Anklagen) en 547.564, sobreseyeron en 241.296 (Einstellungen 』 I53a StPO), aplicaron penas de multas (Geldbetrag) en el 85,I\% de los casos (205.366), trabajos en beneficio de la comunidad (Sonstige gemeinnn. Leistungen) en el I,4\% (3.319) y reparación (Wiedergutmachung) en el 4,7\% (I8.I47). En el año 2000 las cifras decrecieron, respecto a la Wiedergutmachung a un 6,5\% (I6.45I) de 4.447.024 procesos de investigación y 545.274 acusaciones. En lo que respecta al sobreseimiento del $\int$ I53a StPO se aplicó en 252.274 casos. La pena de multa se aplicó en el 86,2\% (2I7.323) y el trabajo en beneficio de la comunidad tan solo en el I,3\% (3.I8I). Ese año comenzó a regir la posibilidad de la Täter-Opfer-Ausgleich (T-O-A) del 『 I53a Nr. 5 como una orden o instrucción (Weisung), aplicándose en el 0,9\% de los casos (2.269). En el año 200I de 4.555.675 procesos investigados, se acusó en 561.314, habiendo sido sobreseídos 258.797, aplicadas multas en el 80,5\% (208.379), trabajos en beneficios de la comunidad en el I,I\% (2.797),

Redur 3 / año 2005 
cuando se deciden por la reparación, prácticamente no consideran la posibilidad de la Täter-Opfer-Ausgleich, limitándose a la solicitud de la reparación del daño material ${ }^{\text {106 }}$.

\section{Conclusión.}

6.I. En este artículo no se ha intentado analizar como puede ingresar la reparación al sistema penal. Tan sólo se han enunciado algunos aspectos de interés del pensamiento de Roxin en relación a la posibilidad de considerar a la reparación como una tercera vía punitiva $^{\mathrm{io7}}$.

Coincidimos en que el sistema penal debe, además de ser un sistema penal mínimo, considerarse como un sistema penal de alternativas ${ }^{\text {108 }}$.

Por ello debemos considerar positivamente la Ley 17.726 de publicación en el Diario Oficial en fecha 7 de enero de 2004, pues aunque no erradica del sistema penal uruguayo la prisión preventiva, al menos, permite al juez en determinadas ocasiones la aplicación de medidas alternativas a la misma ${ }^{\text {rog }}$. Entre estas alternativas, en el artículo

Wiedergutmachung en el 6,3\% (16.246) y T-O-A en el I,O\% (2.548). Por su parte, según datos que surgen de la práctica de los Tribunales StBA-Strafgerichte (Arbeitsunterlage) 1989-200I (ab I993 mit NBL), jew. Tab. 2.3; 4.3, 5.3, 7.3. Additionen und Prozentuierungen nach eigener Berechnung, que en I999, 2000 y 200 I se tramitaron respectivamente I.038.887, I.032.664 y I.0I9.554 procesos; de los cuales fueron sobreseídos en aplicación del 『I53 StPO 8I.459, 77.453 y 76.009 casos; mientras se aplicaron penas de multa en el 8I,I\% (66.065), 79,9\% (61.885) y 77,9\% (59.238); habiéndose producido reparación o Wiedergutmachung en el 9,0\% (7.347), I0,I\% (7.848) y II,5\% (8.707). En lo que respecto a la T-O-A, comenzó a aplicarse en el 200 I habiéndose solucionado por esta vía un $0,5 \%$ (372) de los procesos instaurados. Agradecemos al Prof. Michael Kilchling la aportación de material estadístico.

${ }^{106}$ Respecto de la utilización en la práctica del $\$ I53 StPO por parte de los fiscales, y la limitación al pago exclusivo de los daños y perjuicios, se ha expresado Schöch. NStZ I984, Heft 9, p. 388.

${ }^{107}$ Ha dicho QUINTERO que para que la reparación pueda convertirse en otra de las consecuencias penales junto a las penas y las medidas de seguridad, debería ser introducida en las instituciones penales generales (imposición de la pena, renuncia, sustitución, ejecución) o especiales (concretas clases de delitos). Ver «La Justicia Penal en España», Aranzadi, I998, p. 238.

${ }^{108}$ BUSTOS RAmíreZ «Presente y futuro de la Victimologia», en «Victimologia: Presente y Futuro. Segunda Edicion», Temis, I993, p.52.

${ }^{109}$ Según el artículo 2 la sustitución de la prisión preventiva estará condicionada a que el juez estime que no habrá de recaer pena de penitenciaría (o cuando el mínimo de pena no sea de penitenciaría) y/o cuando se trate de un primario (art. 6). Pero además la norma exige que el juez deniegue este beneficio atendiendo a «la gravedad del hecho» $\mathrm{y}$ «al daño causado». Por nuestra parte entendemos que estas exigencias no deben ser relacionadas con la imprecisa y mediática «alarma social» (que el legislador parecería quiere abandonar) sino con una necesidad preventiva general de defensa social (por eso, también será oído el fiscal) de «no aumentar los riesgos de la población». Parecen superfluas las exigencias de la «gravedad del hecho» y del «daño causado» cuando el juez ya las ha considerado al momento de ponderar «prima facie» la pena que habría de recaer. En el fondo se trata de imponer barreras subsiguientes a la posibilidad de otorgar un beneficio, para no abandonar el cauce conservador-represivo por el que transita desde hace años el sistema penal uruguayo. Una vez más la política criminal seguida por el legislador -obligada por la praxis judicial, de quienes han comprendido que el sistema es demasiado duro con los delitos bagatelarios y permisivo en el sentido contrario- ofrece alternativas en forma tímida y muy condicionada. 
tercero numerales f y c, el legislador ha incluido a la prestación de servicios comunitario ${ }^{\text {IIO }}$ y la «restitución de la situación jurídica anterior a la comisión del delito», las cuales pueden ser consideradas como dos alternativas válidas a la privación de libertad o incluso, como sostiene Roxin, sanciones penales de futuro. Incluso se las puede entender dentro de la «Tercera Vía» a la que en este trabajo se hace referencia. En relación a la «restitución de la situación jurídica anterior a la comisión del delito» debemos interpretar que el legislador se refiere a la reparación en sentido penal, es decir, a la vuelta al status quo anterior al delito, lo que no tiene por qué limitarse a la restitución o indemnización patrimonial de naturaleza civil. De haberse referido a un instituto de naturaleza distinta a la penal debió haberlo expresado en el apartado pertinente. En nuestra opinión la «restitución de la situación jurídica anterior a la comisión del delito» debe entenderse en el sentido de la reparación penal, y en esa línea de pensamiento, no debería acotarse a los delitos patrimoniales, siempre que a través de determinados actos de reparación el autor pueda «compensar» a la víctima (o en su defecto a la sociedad, reparación simbólica) o hacer desaparecer los efectos negativos del delito $^{\text {III }}$.

La reparación como alternativa o sustituto de la pena no debe limitarse a los delitos de daño, también un delito contra el honor puede ser reparado desde un punto de vista penal $^{1 \text { I2 }}$, ya que penalmente relevante es aquel «retorno al status quo anterior al delito» que permita cumplir con los fines de la pena, es decir que devuelva la paz jurídica y que demuestre el interés del autor en re-integrarse a la sociedad; pero además, que brinde satisfacción a la víctima directa en un Derecho penal preocupado exclusivamente por las víctimas potenciales. Así las cosas, reparación en sentido penal no es equivalente a indemnización civil, sino que es mucho más que ésta. La reparación penal puede consistir en una indemnización civil a la víctima o a terceros (por ejemplo, compañía aseguradora), pero también, en un pedido de disculpas a la víctima, una conciliación entre autor y víctima, la realización de trabajos de reparación en beneficio de la víctima o de la comunidad, pagos en dinero a instituciones de utilidad pública, regalos a la víctima, etc. ${ }^{\mathrm{II}}$ Por lo que viene de decirse debe ser bienvenida la reparación como medida sustitutiva de la pena de privación de libertad ${ }^{\text {IIt }}$ ya que toda medida que cumpla con los fines de la pena y signifique un sacrificio menor (principio de necesariedad) debe ser mejor considerada que la pena privativa de libertad. Ahora bien, como ya se dijo, cualquier solución alternativa que se pretenda para la privación de libertad, debería partir de la sujeción de la prisión preventiva a su estricta naturaleza cautelar, esto es, cuando realmente es necesaria a efectos procesales, y

ro Respecto a los servicios comunitarios o «trabajos en beneficio de la comunidad» que se computarán a razón de cada día trabajado como un día de prisión preventiva; con atino el art. 2 exige la aceptación del «beneficiario» para que los mismos no se consideren «trabajo forzoso o forzado».

${ }^{\text {III }}$ Aquí se puede incluir a los delitos patrimoniales, pero también a delitos contra el honor, lesiones leves, delitos contra la Seguridad Social, la Hacienda pública o delitos contra bienes jurídicos colectivos como el medio ambiente; siempre que el daño causado pueda ser «reparado» el juez podría recurrir a esta alternativa a la prisión.

${ }^{\text {II2 }}$ Imaginemos un delito de difamación cometido a través de un medio de prensa que es «desmentido» o «desdicho» por su autor en el mismo medio de prensa, sea por libre voluntad o por mandato del juez, lo importante es que el honor injustamente mancillado puede ser reparado. No debe confundirse esta reparación penal con la posibilidad que tiene el «dañado» de exigir en la vía civil los daños y perjuicios que estime convenientes.

${ }^{\text {ז3 }}$ Como expresa el Proyecto Alternativo de Reparación de i992 en su parágrafo 2.

${ }^{\text {II } 4}$ La reparación como medida alternativa podrá sustituir a la prisión preventiva o a la pena definitiva. Por lo que el legislador permite evitar la privación de libertad cuando esta tiene naturaleza cautelar (prisión preventiva) o cuando tiene naturaleza de pena (art. 9). En la praxis la casi totalidad de las sustituciones se otorgarán al momento de decidir el procesamiento, puesto que aunque queramos evitar el «fraude de etiquetas» y convencernos de la naturaleza cautelar de la prisión preventiva, en nuestro sistema -lamentablemente- ésta es la «verdadera y única pena».

Redur 3 / año 2005 
no, como un adelanto de pena. De otra forma, las alternativas propuestas arrastrarán todos los problemas e inconvenientes derivados de la hiper-utilización del instituto cautelarpreventivo; entre las más objetables, una vulneración notoria del principio de inocencia. En efecto, el procesado que cumpla con los requisitos exigidos para acceder al beneficio alternativo, deberá aceptar la alternativa propuesta o sufrir la privasión de libertad que se pretende evitar, y esto, sin haber sufrido una condena penal en contra, por lo tanto, podría ser conminado a la «restitución de la situación jurídica anterior a la comisión del delito», sobre la base de una presunción de culpabilidad. Pero además, el objetivo de estas alternativas es preponderantemente preventivo especial positivo o resocializador, esto es, el fin de la pena que -por excelencia- se pretende con la ejecución de la misma; con la salvedad que es perseguido en ocasión de la sustitución de una medida cautelar de mero aseguramiento. Así las cosas, se debe remarcar que cualquier alternativa a la privasión de libertad será bienvenida, pero también, que la política criminal uruguaya debe empezar a recorrer un camino más cercano a la ciencia penal y alejarse definitivamente de propósitos exclusivamente políticos. Una vez empezado a recorrer este camino, podrán corregirse todos los desatinos legislativos, especialmente procesales, e intentarse mayores niveles de coherencia sistémica. Que no se siga falseando etiquetas, y llamando medida cautelar a lo que se aplica como castigo retributivo-preventivo, para que las alternativas venideras estén más próximas a solucionar un problema de fondo, antes que cargar a sus espaldas con las mismas críticas que la doctrina ha realizado al instituto que pretenden sustituir. De no actuar el legislador sobre la base de la politica criminal académica, esto es, científica, respetuosa de los principios básicos emanados de la Constitución (por ejemplo, el de presunción de inocencia), coherente con las necesidades sociales y sin crear nuevas antinomias sistémicas, seguirá intentando tapar el sol con las manos, y quienes tenemos la obligación científica de ejercitar nuestra función universitaria en forma crítica (no meramente exegética-descriptiva), seguiremos reclamando las mismas cosas.

En ese sentido, volviendo al tema central de nuestro trabajo, interpretando a la reparación desde un punto de vista penal, es decir, prevención general positiva (retorno de la paz jurídica, de la confianza en la norma, estabilización de la norma como pauta de conducta), prevención especial positiva (menor índice de peligrosidad del autor, intento de retorno a la vida pacifica en sociedad), prevención general negativa (a partir de la exigencia de Beccaria: «certeza y prontitud de la pena antes que severidad») y con el límite de la retribución (proporcionalidad), pueden considerarse determinados actos de reparación como «sustitutos» de la pena, por dar satisfactorio cumplimiento a los fines que con ésta se pretenden obtener.

En el mismo sentido de un Derecho penal de alternativas el parágrafo 167 del öStGB (Código Penal Austriaco) que permite excluir la punibilidad en una serie de delitos ${ }^{\text {II }}$ siempre que el autor -antes que la autoridad pública haya tomado conocimiento del hechorepare directamente o a través de un tercero, el daño ocasionado o se obligue a realizarlo en un determinado plazo de tiempo ${ }^{\mathrm{ri} 6}$.

\footnotetext{
${ }^{\text {II5 }}$ Según el parágrafo I67 del öStGB, en los delitos de: daño, daño sobre datos, hurto, sustracción de energía, abuso de confianza, apropiación indebida, hurtos menores, delitos relativos a la caza y la pesca, estafa, uso fraudulento de datos, obtención de una prestación mediante engaño, recibimiento de regalos por parte de la Autoridad, usura, quiebra fraudulenta, quiebra culposa, receptación en su forma dolosa y culposa, la punibilidad será excluida siempre y cuando se produzca un arrepentimiento activo del infractor. Ver EGMONT FOREGGER-GERHAR KODEK, «Strafgesetzbuch. StGB samt den wichtigten Nebengesetzen. 5. Auflage», Manz Verlag, Wien, p. 427.

${ }^{\text {I16 }}$ A diferencia del $\int \mathrm{I} 67$ öStGB, el $\int 46$ a StGB alemán no limita los beneficios que trae aparejada la reparación a determinados delitos, por lo que los crímenes no estarían excluidos. VER S. WALTHER, cit. p. 324 .
} 
En esta misma línea han trabajado los Profesores alemanes, austriacos y suizos del Proyecto Alternativo sobre la reparación del daño. La Wiedergutmachung -en determinadas situaciones- realizaría una función sustitutiva de la pena, ya que desde el punto de vista de sus fines, efectuada la reparación y restablecida la «paz jurídica», ya no habría necesidad de aplicarla $^{\text {Ir7 }}$. Ahora bien, si las prestaciones de reparación no han sido suficientes para compensar las consecuencias del hecho o si -aun efectuada la reparación- resulta indispensable la imposición de una pena, todavía permanecerá intacta la posibilidad de atenuación de la misma ${ }^{\text {r18}}$. Claro está, tales prestaciones reparadoras deben ser llevadas a cabo dentro de determinado plazo procesal para que puedan tener efectos positivos para quien las realiza ${ }^{\text {II9 }}$.

6.2. Roxin ha propuesto una serie de sanciones «similares a la pena», que no serían penas propiamente dichas, puesto que por un lado imponen algo al autor, pero por el otro carecen del carácter coercitivo de la misma.Se refiere el Profesor alemán a tres sanciones en especial: a) el trabajo en beneficio de la comunidad $^{120}$, b) la reparación voluntaria ${ }^{\mathrm{r21}}$ y c) las sanciones contra entes colectivos ${ }^{\mathrm{I} 22}$.

${ }^{\text {Ir7 }}$ Ver $\int 4$ AE-WGM: «Reparación en vez de pena: (I) Si el autor ha reparado su hecho ( $\int \mathbb{I}$ I,3) el tribunal prescindirá de la pena, a menos que la pena sea indispensable para influir sobre el autor o la colectividad. (2) La no dispensa de la pena a que se refiere el apartado I sólo se producirá, por regla general, cuando sin la reparación el autor hubiera merecido una pena privativa de libertad de más de un año».

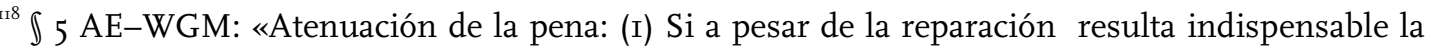

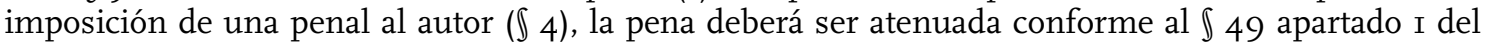
Código Penal. (2) Lo mismo rige cuando las prestaciones de reparación efectuadas por el autor no hayan compensado las consecuencias del hecho de forma completa, pero sí en gran parte. Según el grado de compensación alcanzado, el tribunal puede atenuar la pena según su criterio ( $\mathbb{\int} 49$ apartado 2 del Código Penal)».

Ir9 \6 AE-WGM: «Límites temporales para prestaciones de reparación: (I) La renuncia a la pena conforme a $\mathbb{\int} 4$ y la atenuación de la pena conforme a $\ 5$ presuponen que el autor haya realizado la reparación antes de la apertura del juicio oral, a menos que no le fuera exigible hasta este momento a causa de circunstancias especiales. (2) Si el Ministerio Fiscal ha presentado una querella pública en la que realiza la petición de un mandamiento penal, basta, en caso de un recurso admisible, con que el autor repare su hecho hasta el comienzo del primer juicio oral $\left(\mathbb{\int} \int \mathrm{I}, 3\right)$ ».

${ }^{\text {ז20 }}$ Por ejemplo, trabajos en hospitales, asilos y establecimientos estatales de todo tipo. Esta sanción podría reemplazar a la multa, siempre que el autor se ofreciera voluntariamente a ello. Desde el punto de vista criminológico es de interés la consulta de los trabajos realizados en Suiza por M. Killias, M. AEBi Y RiBEAUd D: en colaboración con RöSli P, Le travail d'intérêt général dans le canton de Vaud: Rapport sur le TIG avec une comparaison entre un groupe expérimental et un groupetémoin randomisés, Lausanne: Université de Lausanne, Institut de police scientifique et de criminologie, I997. Disponible en Internet: http://www.ofj.admin.ch/themen/stgb-smv/bermv/I9.pdf; en colaboración con RIBEAUD D., «Does Community Service Rehabilitate Better than Short-term Imprisonment? Results of a Controlled Experiment», The Howard Journal of Criminal Justice 39/I (2000): 40-57; KILliAS M., AEBI M.F. \& RiBEAUD D., «Learning Through Controlled Experiments: Community Service and Heroin Prescription in Switzerland», Crime \& Delinquency 46/2 (2000): 233-25I.

${ }^{\text {I2I }}$ El traductor ha preferido referirse a la «reparación civil voluntaria», pero la tercera vía a la que se refiere Roxin en reiterados trabajos, va más allá de la simple reparación civil del daño. Es así que he preferido referirme a la reparación del daño respecto a la palabra alemana Wiedergutmachung o Schadenswiedergutmachung. Ver «El desarrollo del Derecho Penal», obra cit, p. 459.

${ }^{122}$ Dice Roxin que este tipo de sanción, sin llegar a ser una verdadera pena, «constituye en todo caso una sanción similar a la penal, vinculada con la realización de tipos penales, y ello es suficiente para confirmar mi tesis de la futura diversificación de las reacciones penales». Ibidem, p. 462 y ss.

Redur 3 / año 2005 
Respecto a la reparación del daño, aclara que ésta debe ser voluntaria, por lo que se distancia del modelo francés (action civile) o inglés (compensation order) ${ }^{123}$ que pueden ser impuestos por el juez penal ${ }^{\mathrm{I} 24}$, o solicitados por la víctima, como si de una compensación por daños y perjuicios se tratara ${ }^{\text {r25 }}$. A la vez que sostiene que finalizado el proceso penal, cualquiera de estas dos soluciones apenas proporcionan a la víctima un título ejecutivo que carece de valor cuando el autor es insolvente o se sustrae a la ejecución ${ }^{\mathrm{r2} 6}$. Esto significaría tan sólo el traslado de la demanda civil al proceso penal en cumplimiento de los principios de celeridad y economía procesal; pero en pocos casos, se daría real satisfacción a la víctima $^{\mathrm{I} 27}$. Pero además, desde un punto de vista político-criminal, en nada colabora con la punición, el hecho que la pena y la indemnización transcurran juntas, pero en forma independiente $^{\mathrm{r} 28}$. En opinión de Roxin, la idea que ofrece más perspectivas de futuro, «es que una reparación civil prestada voluntariamente hasta la apertura del juicio oral debe llevar a una atenuación obligatoria de la pena». Pero yendo aun más allá, puede llevar incluso a una «exención de la pena en los casos apropiados de delitos menores (quedando en pie la declaración de culpabilidad) ${ }^{\text {t29. }}$.

Esta propuesta de Roxin respecto a una específica sanción para las personas jurídicas no tiene respaldo normativo en Alemania. En el presente no existe ningún precepto similar al art. I29 del Código Penal Español que permita sancionar a los entes colectivos. El principio «societas delinquere non potest» aún goza de excelente salud en Alemania. Sobre la temática de las personas jurídicas, ver el trabajo de Habilitación de GÜNTER HEINE, «Die strafrechtliche Verantwortlichkeit von Unternehmen», Nomos-Verl.-Ges., Baden-Baden, I995.

${ }^{\mathrm{I} 23}$ La reparación como sanción ocupa un incómodo lugar entre la pena, la medida (rehabilitadota, reparadora o sui generis) y la deuda civil. Cfe. S. WALTER, cit. p. 325.

${ }^{124}$ Sin embargo no es ajeno al sistema alemán, que el juez pueda exigir la reparación del daño a la víctima o el esfuerzo del autor hacia una conciliación reparadora de la paz jurídica. Es así como en la justicia de menores ( $\$ Io Abs. I S. 3 Nr. 7 JGG ) puede el tribunal exigir como «medida educativa» que el autor «sich zu bemühen, einen Ausgleich mit dem Verletzten zu erreichen». Esta exigencia imperativa (no voluntaria), se ha criticado por parte de la doctrina, sosteniendo que es inapropiada. Por ese motivo desde su implementación (I.I2.I990) apenas en algún caso de relevancia se ha exigido esta «erzieherischen Ma nahme». Ver H. SСHÖCH, «Wege und Irrwege», cit. p. I050.

${ }^{125}$ En el sistema norteamericano, la reparación del daño como sanción se limita al daño material, no cubriendo otros daños no materiales. Según T. WeIGEND, «Restitution in den USA», en ESER/KAISER/MADLENER, cit. p.II6.

${ }^{126}$ RoXIN, «Pena», cit. p. 8.

${ }^{127}$ RoXIN, »El desarrollo»,cit., p. 459. La solución debería provenir de un proceso penal que tienda al consenso siempre que sea posible y no merme ninguna de las garantías del imputado. Sin embargo, en situaciones en las que el propio imputado reconozca su responsabilidad en los hechos (o sepa de sus pocas posibilidades de ser absuelto) sería del interés de todos los participantes del proceso penal el arribar a una solución de reparación y entendimiento. Tanto el lesionado como el Estado tienen interés en un acuerdo compensatorio entre autor y víctima; así como el autor pretende una atenuación (o librarse) de pena. Ver, «Pena», cit. p. I4 y ss.

${ }^{128}$ Explica Roxin, que el hecho de que la prevención sea un fin de la pena, no quita que pueda ser impulsada con herramientas del Derecho civil o del Derecho público y renunciar a una penalización, siempre que se pueda conseguir un efecto preventivo suficiente con medios ajenos al Derecho penal. «De esta manera analógica se podría pensar en erigir a la reparación como un fin, entre otros, de la pena y dejar influir su producto sobre la punibilidad, bajo reconocimiento de su (por lo menos parcial) carácter jurídico-civil». Cfe. «Fines de la pena», cit. p. I46.

${ }^{129}$ RoXIN, «El desarrollo.. », cit. p. 460. Parte de la doctrina italiana acompaña el pensamiento de Roxin respecto a un posible «terzo modello» de sanción penal, en calidad de sanción sustitutiva de la pena privativa de libertad. Se comienza a percibir un alejamiento de la visión puramente civilista del Codice Rocco, por lo que en algunos ámbitos, «il risarcimento del danno» empieza a tener un espacio en condición de sanción autónoma, una «dritte Spur» que sobretodo en el sector relativo a los delitos contra el patrimonio o algunos contra la personalidad, bien podría cumplir una función sustitutiva 
Esta medida tiene a su vez la ventaja de acercar las posiciones de los derechos penal y civil ${ }^{130}$.

6.3. La protección de la víctima debe ser una de las funciones del derecho penal, y este hecho por sí solo justifica la inclusión de la reparación en el ámbito del sistema penal material y procesal ${ }^{13 \mathrm{I}}$.

Por lo tanto, «junto a la pena se tendrá que emplear elementos de dirección sociopolítica muy diferenciados y flexibles, vinculados a una conducta punible, pero de carácter solamente similar al de una pena» ${ }^{132}$. La pena no podrá ser eliminada (abgeschafft) pero puede ser a través de la Wiedergutmachung moderada (gemildert), modificada (modifiziert) e incluso parcialmente sustituida (teilweise ersetzt). Como ha dicho Roxin, en respuesta a alguna de las críticas a su posición -especialmente de Hirsch-, la sustitución de la pena por la Wiedergutmachung no es algo tan revolucionario como lo plantean algunos penalistas «Conservadores ${ }^{133}$.

Debe quedar claro que la reparación del daño sin finalidad ulterior es un fin del Derecho civil. Sin embargo, la reparación integral (Wiedergutmachung) que otorga satisfacción a la víctima y conjuntamente a la sociedad en general (restaurando la «paz

de la pena de privación de libertad. Vide, ADELMO MANNA, «Le nuove prospettive sanzionatorie a tutela della vittima nel diritto penale», en Scritti in Memoria di Renato Dell'Andro. Vol. I, cit. p. 5I4.

${ }^{130}$ Si bien esa separación entre los Derechos penal y civil pudo tener cierta lógica dentro de la sistemática del derecho, y por eso haber sido comprendida; no causó felices efectos desde el punto de vista socio-político. Ver RoxIN, «Die Wiedergutmachung im strafrechtlichen Sanktionensystem», en Wege und Verfahren des Verfassungslebens. Festschrift für Meter Lerche zum 65. Geburtstag, Hergs. Badura/Scholz, München, I993, p. 30I. Podría intentarse la combinación en un mismo proceso, por un lado del interés del Estado en el castigo del delincuente y por el otro, el de la víctima hacia la reparación del daño. En ese sentido, SUSANNE WALTHER cree que una posible vía de acercamiento, podría ser la que siguen Francia, España o los países nórdicos, donde en el propio proceso penal se dirimen aspectos civiles tendentes a la reparación a la víctima. No se puede seguir con viejos arquetipos cuando ambos procesos cumplen funciones de prevención y reafirmación de la norma en el Estado moderno, «and both the criminal law and the civil law protect "legal goods". What remains is this: to contrast the archetypal mandates of criminal law and civil law, as discernible from the constitutive principles of the modern state». Cfe, «Reparation and Criminal Justice: can they be integrated?», cit, p. 326,328 y 329 .

${ }^{13 \mathrm{I}}$ En el derecho penal español la protección de la víctima puede incluso ser considerada de orden constitucional según dispone el art. 24 Constitución Española. La Ley de Enjuiciamiento Criminal (LECRIM) en su artículo Ioo, siguiendo el modelo francés permite la acumulación de acciones civil y penal, ya que «también el proceso penal ha de convertirse en un instrumento útil para la reparación de la víctima». Ver, V. Gimeno Sendra, Moreno Catena, Cortés Domínguez, «Derecho Procesal Penal. $3^{\text {a }}$ edición septiembre I999. Reformada y actualizada», Colex, I999, p. 44.

${ }^{132}$ RoxIN, «El desarrollo», cit., p. 463. La reparación sería una novedosa forma de sanción que aparece al lado de las penas y las medidas de seguridad, pero de naturaleza independiente. Su autonomía reside en el hecho de que no es impuesta al autor de tal forma que sólo tenga la opción de aceptarla y cumplirla. Al contrario, en este tipo de sanción es el autor quien asume la responsabilidad $\mathrm{y}$ «tiene que colaborar activamente para restablecer la paz social perturbada». Cfe. «Pena», cit. p. I3. La reparación para Roxin, a pesar de integrar el sistema de sanciones, no significa una reprivatización del derecho penal ni una pena especial ni un nuevo fin de la pena. Se trata de una prestación autónoma (una sanción autónoma) que puede permitir alcanzar los fines tradicionales de la pena y, en la medida que lo logre, «debería sustituir a la pena o ser computada para atenuarla». Vide, «Fines»; cit. p. I54.

${ }^{133}$ «Die Ersetzung der Strafe durch Wiedergutmachung ist nicht so revolutionär, wie das manchen konservativen Strafrechtlern erscheint». Cfe. RoxIN, «Die Wiedergutmachung», cit. p. 3I3.

Redur 3 / año 2005 
jurídica»), encaja perfectamente dentro de los fines de la pena (Strafzwecke). Además, como ya dijéramos, en determinadas situaciones ${ }^{\mathrm{I} 34}$, la «restauración» de la situación a su estado original (o su esfuerzo significativo) a través del comportamiento positivo posterior del delincuente, puede llevar a que la pena no sea «necesaria» o, desde el punto de vista del derecho procesal penal, que la propia acusación fiscal no sea necesaria, decretándose el sobreseimiento provisional de la causa ${ }^{\mathrm{T} 35}$.

6.4. Así las cosas, luego de esta somera exposición, deberíamos dejar planteados algunos interrogantes, de ser posible, como contribución al necesario debate que este tema exige.

6.4.I. En lo que refiere a la práctica del Derecho penal en Alemania, específicamente en cuanto atañe a las cifras expuestas ${ }^{136}$, debemos expresar que no es éste el lugar ni el momento apropiado para intentar una explicación de este fenómeno propio de la praxis germana; tarea que por otra parte corresponde realizar a la Criminología. Sin embargo invita a la reflexión, el hecho de que la finalidad perseguida por el legislador (obviamente influenciado por las resultancias del AE-WGM y la posibilidad de esta tercera vía) no tenga acogida en la praxis de los tribunales.

De alguna forma se produce una antinomia entre la situación de bienestar social de la población alemana, que fácilmente podría recurrir a la reparación como vía alternativa de solución del conflicto y la poca utilización de medios alternativos de solución relacionados con la reparación del daño. Así como se ha sustituido a la privación de libertad por penas de multa en la gran mayoría de las condenas, nada parecería impedir que la reparación sustituyera -a su vez- a la multa.

Ahora bien, como sucede generalmente, creemos que la explicación de esta nueva antinomia no provendrá de la Política Criminal, sino de la Sociología procediendo a analizar la política en general. Es así que una explicación posible a tal circunstancia puede provenir desde la propia condición de Estado de bienestar (Wohlfahrtstaat) que no se condice con la

${ }^{\mathrm{i} 34}$ Ver por ejemplo el $\int 46 \mathrm{StGB}$, parte final, «cuando no se deba aplicar una pena mayor de un año de privación de libertad o de una multa de hasta trescientos sesenta días-multa, privar de pena».

${ }^{135}$ Ver $\int$ I53 StPO respecto a la no persecución de litigios de mínima cuantía en ocasión del principio de oportunidad, en tanto se trate de delitos (no de crímenes) y la culpabilidad del autor pudiera ser considerada de poca entidad. De esta manera no existiría un interés público en la persecución penal. Según el $\int$ I53a StPO la fiscalía puede llegar a prescindir provisionalmente de la interposición de la acción pública y en su lugar exigir al inculpado: I. «una determinada prestación para la reparación del daño ocasionado por el acto, 2. pagar un importe en favor de una institución de interés común o del Tesoro público, 3. aducir otras prestaciones de interés común, o 4. cumplir con deberes de alimentos de un determinado valor», siempre que estas imposiciones e instrucciones sean apropiadas para suprimir el interés público en la persecución penal, y siempre que no se oponga la gravedad de la culpa. Para que se cumplan estas «imposiciones» se requiere el consentimiento del inculpado. También por el \I53b StPO, dadas las condiciones bajo las cuales el tribunal podría prescindir de la pena, con el consentimiento del tribunal, se puede prescindir de la acusación o si ya ha sido interpuesta, decretarse el sobreseimiento. Vide B. BANNENBERG, «Wiedergutmachung in der Strafrechtspraxis», Göttingen, I993. Para datos criminológicos respecto a la T-O-A, E. Dölling, «Täter-Opfer-Ausgleich. Eine Chance für Opfer und Täter durch einen neuen Weg im Umgang mit Kriminalität», Herausgegeben vom Bundesministerium der Justiz, Bonn, I998, Forum Verlag Godesberg.; D. RöSSNER, «Mediation als Element der strafrechtlichen Sozialkontrolle», en Die Stellung des Opfers im Strafrechtssystem. Neue Entwicklungen in Deutschland und in den USA, Hrgs. B. SCHÜNEMANN/MARKUS DUBBER, Sonderdruck, 2000.

${ }^{136}$ Nota de pie de página I05. 
posibilidad de dejar el conflicto en manos de sus verdaderos protagonistas. La esencia del mismo lo impide ${ }^{137}$.

Así las cosas, viendo la poca aplicación práctica que tiene la Wiedergutmachung en Alemania ¿debemos suponer que nuestras sociedades latinoamericanas podrían afrontar con mejor éxito tal desafío? Pues bien, siguiendo en una línea argumental sociológica la respuesta debería ser afirmativa. El Estado liberal podría ser considerado como el modelo opuesto al Wohlfahrtstaat. En este sistema el individuo debe procurarse por sus propios medios el bienestar que el Estado no le brinda ni garantiza. El Estado liberal cumple un mero rol de vigilancia y control de determinadas áreas previamente reglamentadas, pero siempre en un sistema que preferencia la libertad absoluta de la oferta y la demanda. Así las cosas, en un sistema que potencia la individualidad antes que lo colectivo, o el éxito personal antes que la solidaridad social, es más factible que se pueda admitir una propuesta relacionada con la solución del conflicto a través de una mayor ingerencia de las partes involucradas en el mismo.

Sin embargo y a modo de paradoja: el modelo de Estado que menos ofrece es el que más exige y reprime.

En la gran mayoría de los países latinoamericanos, la privación de la libertad es la pena por excelencia. Pero además -a efectos de disminuir aún más las garantías y continuar violando el principio constitucional de presunción de inocencia - tal privación de la libertad se aplica como prisión preventiva y no como pena ${ }^{\mathrm{I} 38}$.

Así como el Wohlfahrtstaat utiliza el Derecho penal para la reafirmación de la norma (su propia existencia), el Estado liberal se sirve del Derecho penal para infundir temor en la población y segregar por algún período de tiempo a sujetos con algún grado de peligrosidad.

De esta manera, ambos modelos de Estado y sus respectivos sistemas penales se enfrascan en la consecución de distintas finalidades preventivo-generales, fracasando por completo en lo que refiere al cumplimiento de las finalidades preventivo especiales que la pena debe cumplir. Por tanto, debería ser acogida con mucho mayor beneplácito por la doctrina latinoamericana una solución próxima a la reparación antes que una solución punitiva ${ }^{139}$. En Latinoamérica -salvo contadas excepciones- el Estado apenas cumple con la finalidad preventiva-general-negativa de la pena; y sostener que la reafirmación de la

${ }^{\mathrm{r} 37}$ A cambio del ofrecimiento del bienestar social el Wohlfahrtstaat exige parte de la libertad de los individuos beneficiarios del mismo. De esta forma, el Estado -como sucede generalmente con los benefactores- asume como contrapartida un poder monopólico de resolución de todas las cuestiones sociales. Esta «omnipresencia» en dichos asuntos se confirma de continuo al momento de solucionar los conflictos de la sociedad, con especial relevancia en las cuestiones penales. A través del Derecho penal el Estado, especialmente al momento de la aplicación de la pena, reafirma su condición de Estado social a través de la confirmación del derecho que lo sustenta y legitima. La reafirmación de la norma no es otra cosa que la autoconfirmación de sus potestades para exigirles a los individuos la obediencia que se debe a quien tanto les ofrece desde el punto de vista de la calidad de vida.

${ }^{138}$ La prisión preventiva, como medida cautelar que es, debería aplicarse sólo cuando estuviera justificada y ser temporalmente restringida. Sin embargo, como uno de los mayores fraudes de etiquetas de nuestros sistemas penales, se convierte en la única pena.

${ }^{139}$ Por designio constitucional las penas deben servir a la resocialización de los individuos o para su pronta reinserción en la sociedad. Este fin se puede conseguir con mejores posibilidades de éxito -como ya explicáramos- a través de la reparación. En efecto, la reparación implica una suerte de reconocimiento del hecho a la vez que la demostración cabal de la voluntad del autor de retornar a la pacífica vida en sociedad.

Redur 3 / año 2005 
norma es la meta del Derecho penal de nuestros países significa lo mismo que reconocer y asumir que nada debe cambiar ${ }^{\mathrm{r} 40}$.

Así las cosas, sólo cabe recalcar que el mayor problema que afronta la reparación como alternativa punitiva, es la tendencia -cada vez más acentuada- al control de la sociedad a través del Derecho penal. En este aspecto ambos modelos de Estado se oponen a que la reparación ocupe un lugar dentro de las alternativas a la pena ${ }^{\text {I4t }}$.

6.4.2. En cuanto atañe a la discusión de fondo, nosotros no vislumbramos considerando el estado actual de la misma- la posibilidad de habilitar una tercera vía punitiva, básicamente por una cuestión de fundamentos dogmáticos, pero también de política criminal.

Todavía la tercera vía no ha logrado conseguir el fundamento que ya poseen las dos vías punitivas existentes. Esto es: la culpabilidad como medida (y límite máximo) de la pena y la peligrosidad para las medidas de seguridad ${ }^{142}$. Puede, por el contrario sostenerse, que la reparación tiene la misma justificación que las penas y las medidas, ya que suponen la comisión de un hecho antijurídico y que todas ellas consideran el pasado tanto como el futuro en sus aspectos preventivos; así como pueden limitar las metas político-criminales preventivas por la vía del principio de proporcionalidad. Al fin y al cabo, lo que realmente importa es la búsqueda de metas comunes a todas las consecuencias jurídicopenales, en el respeto de las bases garantistas del Derecho penal liberal. Esto inmerso en la búsqueda permanente de una ejecución punitiva que respete al ser humano en lo que a su dignidad se refiere; y de ser posible, acorde con sus posibilidades de cumplimiento. Sin embargo, político-criminalmente se podría solucionar con mayor efectividad el problema de la pena, recurriendo al principio de subsidiariedad ${ }^{\mathrm{I} / 3}$ dentro de las alternativas a la pena (si se pretende dotar a la reparación de carácter punitivo), sin que tenga que constituirse la reparación en una categoría propia de la punición. La reparación puede cumplir su función de alternativa de la pena en general, atendiendo al principio de subsidiariedad, en base al cual el juez podría exigir la reparación en lugar de la pena privativa de libertad y de la multa, como otra de las alternativas a la pena ya existentes.

\footnotetext{
${ }^{140}$ No se condice una posición funcionalista radical -que al parecer ha seducido a parte de nuestra doctrina- que persiga la reafirmación de la norma y del sistema como fines primordiales de la pena y del Derecho penal, con nuestra realidad cotidiana. Por más que como dogmáticos nos parezca perfecta y admiremos su precisión; o se diga que su «abstracción» es de tal magnitud que podría ser aplicada en cualquier realidad política o social, un sistema dogmático pensado y desarrollado (en exclusiva) para un país como Alemania, no puede ser trasladado «sin previo pasaje por Aduana» a Colombia o Argentina, por citar algunos ejemplos en particular. Nuestras sociedades y en especial nuestros penalistas deben asumir permanentemente una posición crítica, realizar una dogmática crítica. No podemos defender un sistema que no consideramos justo. Por tanto, siguiendo la línea de pensamiento de Radbruch debemos sostener que será la «mala conciencia del penalista» la que deba dominar nuestras acciones futuras.

${ }^{144}$ Justamente es a través de la pena que el Estado aumenta su control sobre los ciudadanos. En Estados de bienestar como Alemania mermando su patrimonio a través de la multa. En los Estados liberales latinoamericanos a través de la privación de libertad.

${ }^{142}$ A pesar de que -a diferencia de lo que sucede con las penas- muy poco se discute sobre los fines de las medidas. Sin embargo el consenso surge de que se trata de la otra gran forma de control social. Ver HASSEMER-MUÑOZ CONDE, «Introducción a la Criminología y al Derecho Penal», tirant lo blanch, Valencia, I989, p. I64.

${ }^{143}$ En el sentido de recurrir a la sanción menos severa siempre que ello sea posible según los fines preventivos propios de las sanciones jurídicopenales.
} 
Pero, si lo que se quiere es dotar a la reparación de un fundamento exclusivamente voluntario, entonces, en aplicación del criterio de necesidad de pena, el juez podrá prescindir de la pena siempre que ello sea posible. Lamentablemente el grupo de delitos que el legislador alemán ha comprendido dentro de esta posibilidad es escaso, limitándose prácticamente a los delitos de bagatela. Mientras no se produzca una ampliación del número de delitos pasibles de ser eximidos de pena operada la reparación, la misma deberá seguir cumpliendo con su importante rol de atenuación de la culpabilidad.

No estamos proponiendo dejar todo como está, ni cambiar algo para que todo siga igual; puesto que el legislador podría decidirse directamente por la despenalización de aquellas figuras de insignificancia penal o derivar al Derecho civil o administrativo sancionador, en aplicación de los principios de fragmentariedad y ultima ratio, aquellas otras que podrían ser solucionadas por esas vías sin resentimiento de las finalidades de prevención ${ }^{\mathrm{r} 44}$. Creemos que ésta temática debería ser analizada con mayor detenimiento, e intentar comprender con mayor pulcritud y menos apego a aspectos filosóficos o de pura política criminal, cuales son las causas que podrían impedir la aceptación del nuevo carril punitivo que Roxin -fundamentalmente $-{ }^{\mathrm{I} 45}$ propone. Si bien es cierto que la pena y la medida de seguridad no cumplen con los fines que deberían cumplir, gozan de la protección que brindan el fundamento de la culpabilidad y la peligrosidad. A pesar del dominio funcional y de las necesidades de solución de los problemas, todavía hay quienes entienden que en determinados sectores de relevancia, la dogmática debe erigirse en la barrera de la política-criminal. Es así que la búsqueda de ese fundamento dogmático es el gran desafío futuro de la reparación para encontrar su correcto lugar en nuestra ciencia.

En tanto refiere al ámbito latinoamericano, en aras de una mejor consideración de la víctima ${ }^{\mathrm{I} 46}$, mientras tanto el Estado no asuma la reparación pública como una posibilidad $\operatorname{cierta}^{\mathrm{I} 47}$; quizás, la propuesta de utilizar la reparación como una alternativa -no sólo- a la

${ }^{\text {I44 }}$ Ver ADELMO MANNA, «Beni della personalità», cit. p.92 y SS., p. 682 y ss; DÉSIRÉE FONDAROLI, «Illecito penale», cit. p. 563 .

${ }^{\text {I45 }}$ No podemos desconocer la propuesta de DETLEV FREHSEE, «Schadenswiedergutmachung als Instrument strafrechtlicher Sozialkontrolle. Ein kriminalpolitischer Beitrag zur Suche nach alternativen Sanktionsformen»; Duncker \& Humblot, Berlin, I987, p. II9; tampoco el pensamiento de SCHÖCH y BAUMANN (obras citadas) en esa dirección. Sin embargo la extensión de este trabajo impide cualquier otra consideración de las mismas.

${ }^{146}$ No sólo olvidada en muchos de los procesos penales de la región, sino además, secundariamente victimizada por los distintos órganos de investigación. La víctima en nuestro continente sólo sirve como medio de prueba en la búsqueda afanosa de la verdad material. Ver «Las reformas procesales penales en América Latina» JULIO MAIER coord., Ad-hoc, 2000.

${ }^{147}$ Esto teniendo en cuenta que gran parte de la delincuencia económica y de cuello blanco, y en el otro extremo, contra el patrimonio y las personas, es consecuencia de las continuas y erróneas políticas económicas estatales. Amén de esto, así como la Victimodogmática exige una actuación responsable de la víctima en cuanto a no colaborar con su imprudencia (negligencia o impericia) con el autor facilitándole la comisión del delito, también sería saludable el análisis de la posibilidad de que los Estados -en general- se constituyeran en responsable civil solidario en todas aquellas situaciones en que el delito se haya cometido (o haya sido facilitado), por ejemplo, por deficiente prevención policial, por problemas políticos o étnicos o cuando el autor se haya insolventado utilizando los beneficios que otorga una plaza financiera o bancaria complaciente. Situaciones todas que pueden favorecer al autor en lo que refiere a la comisión de determinados delitos, facilitados por la imprudencia (negligencia o impericia) del Estado.

Redur 3 / año 2005 
privación de libertad, sino también a la pena de multa, pueda tener mejores resultados en nuestras sociedades ${ }^{148}$.

6.5. Lamentablemente la doctrina es conteste en que si bien mucho se dice sobre la necesidad de un derecho penal que se oriente hacia la reparación del daño o que al menos intente resarcir a las victimas del delito, poco y nada se hace en la práctica, como si todavía no fuese un tema de interés. Se sabe y se ha escrito ${ }^{\text {I49 }}$ sobre cual es el camino a seguir, pero sólo ha habido una tímida decisión respecto a comenzar a andarlo. Al parecer no se asume la posibilidad de que el derecho penal abandone su filosofía represiva y pueda cumplir con fines constructivos, de auténtica pacificación social ${ }^{150}$.

Deberíamos analizar con mayor detenimiento, que causas impiden la aceptación de un nuevo carril punitivo. Al fin y al cabo, el sistema vicarial lejos se encuentra de ser la panacea en esta materia ${ }^{\mathrm{ISI}}$. No podemos descartar esta nueva propuesta sin una discusión más profunda.

Se dice que se ha producido un cambio de paradigma. La espada de Damocles que pende sobre el delincuente puede llegar a no pesar tanto. A efectos de motivar -más aun- a los autores de determinados delitos hacia la reparación, se deberían abarcar -además de la atenuación y/o suspensión condicional de la pena- otras consecuencias penales que incrementen la motivación del individuo hacia la realización efectiva del comportamiento positivo posterior. Entonces, el propio autor aceptará también «su castigo» o «reproche social» en forma voluntaria y no como una injusta imposición. Mejor aun si pudiera obtener una exoneración de pena o el sobreseimiento tras una conciliación reparadora con la víctima. De esta forma, el derecho penal podría empezar a cambiar en la dirección que pretendía Gustav Radbruch ${ }^{152}$ y -ahora- pretende Claus Roxin. Por tanto, mientras la sociedad no encuentre «algo mejor» que el Derecho Penal para la solución de los conflictos sociales, la función de éste acorde con la actual teoría de la pena, exige que las sanciones previstas en el Código de los fracasos sociales, no se conviertan -también- en fracasos político-criminales.

${ }^{148}$ De opinión similar HASSEMER y MUÑOZ CONDE: «Propuestas como ésta tienen un futuro halagüeño en tanto sirvan como alternativas a la pena de prisión». «Introducción», cit. p. I74.

${ }^{149}$ Ver Proyecto Alternativo sobre reparación, AEW (Alternativentwurf Wiedergutmachung) de I992; COUNCIL OF EUROPE, «Explanatory Reporto $\mathrm{n}$ the European Convention on the Compensation of Victims of Violent Crimes», Strasborug, I984; «The Position of the Victim in the Framework of Criminal Law and Procedure», Strasbourg, I985; UNITED NATIONS, «Seventh United Nations congress on the Prevention of Crime and the Treatment of Offenders», New Cork, I986. Tomando en consideración a las víctimas de los delitos, tanto la ONU como la Unión Europea, han venido señalando que la meta principal del proceso penal no debería ser la imposición de una pena como reafirmación del poder estatal o institucional, sino la solución del conflicto a través de medios menos formales, rápidos, menos costosos, y que tengan en cuenta la reparación de la víctima como una de sus metas.

${ }^{\text {I5o }}$ En sentido similar L. FRÜHAUF, cit., p. I.

isi Como expresa RoXiN: «el resultado de los esfuerzos resocializadores actuales es tan desilusionamente que sólo ya por ese motivo se debe emprender continuamente algo nuevo». Cfe. «Fines de la pena», cit. p. I53.

${ }^{\text {I52 }}$ RADBRUCH/WOLF, «Rechtsphilosphie», Koehler, Stuttgart, I963; RADBRUCH/ SCHMIDT, «Eine Feuerbach-Gedenkrede. Sowie drei Aufsätze aus dem wissenschaftlichen Nachla», Tübingen, Mohr, 1952 . 
Una vez más, Claus Roxin nos invita a reflexionar sobre un tema de crucial interés, particularmente para el mundo hispanoamericano. El debate no está cerrado ${ }^{\mathrm{T} 53}$, sino al contrario: recién comienza.

${ }^{\mathrm{I} 53}$ El ingreso de la reparación en el sistema sancionatorio debe permanecer en el orden del día. RoxIN, «Die Wiedergutmachung», cit. p. 313; siendo uno de los desafíos que nuestra ciencia debe abordar. SUSANNE WALTHER «Reparation», cit. p. 326; SCHÖCH, «Wege und Irrwege», cit. p. Io64.

Redur 3 / año 2005 